Ljiljana Marković

Univerzitet u Beogradu

Filološki fakultet
316.422(520)

https://doi.org/10.18485/climb.2017.5.2.ch2

\title{
MODERNIZACIJA JAPANA
}

- I KULTURA I NAUKA-

\section{Sažetak}

Japansko duhovno nasleđe, etičko, estetsko, filozofsko, književno utkano je u procese modernizacije umetnosti i napretka nauke, samim tim i života u Japanu. Analizom filozofskih i moralnih stavova Kasnije Mito (水戸) škole, kao i pregledom razvoja japanske književnosti, naročito proznih žanrova, koji vode nastajanju katkad i trivijalne književnosti, pokazuje se autohtonost i izvornost japanskog stvaralaštva i njegov upliv i odgovor izazovima i potrebama modernizacije japanskog društva. Modernizacija Japana je utoliko bila uspešnija ukoliko su joj put utirale i nauka i kultura i privreda.

Ključne reči: Kasnija Mito škola, japanski roman, modernizacija Japana.

U svetu će se često čuti rečenica da je Japan za dvadeset godina uradio ono za šta je Evropi i ostatku sveta trebalo više od dve hiljade godina postao moderna država. Ovo bi se vrlo lako moglo uzeti kao tačna izjava, ako pogledamo Japan na početku devetnaestog veka i Japan samo tridesetak godina posle restauracije Meiđi. Da bi se imao kompletan uvid u proces modernizacije Japana, potrebno je prvo objasniti istorijske okolnosti u kojima se ovaj proces odvijao.

Na samom početku sedamnaestog veka, Japan je ušao u samoizolaciju i time se praktično odsekao od skoro svih informacija vezanih za kulturu, politiku, napredak nauke i uopšte događaje izvan države. Ovo je, naravno, važilo za običan svet, dok je, sve vreme izolocije postojao i veoma mali krug ljudi koji je, iako u nužno ograničenom obimu, bio u toku sa novitetima i događanjima van Japana i koji je znao koliko Zapad napreduje. 
Svakako ne odmah na početku ovog perioda, ali već od osamnaestog, a pogotovo od devetnaestog veka, jaz između Zapada i Japana bio je ogroman. Skoro u svakom polgedu. Japan je zaostajao u tenhici i tehnologiji, moderno razvijen pravno-birokratski sistem nije postojao, državni vrh nije bio dobro uređen, ustav je bio zastareo (bar u odnosu na kriterijume sa Zapada), umetnost je trpela, nauka nije mogla da napreduje, medicinska nauka se zasnivala na drevnim kineskim spisima dok je na Zapadu postala egzaktna nauka.

Modernizacija jedne države predstavlja vrlo specifičan proces $u$ kome svaki deo društva mora dati svoj udeo, a da bi se to ispunilo jedno društvo mora biti spremno da preduzme sve što je potrebno kako bi dati proces bio uspešan. Ako pođemo od stanovništva, ono mora biti dovoljno obrazovano da bi nosilo celokupan proces promena. Državni aparat mora biti posebno osposobljen da sagleda specifičnosti svog naroda, da sagleda promene u svetu i da vidi šta od toga treba prihvatiti, a šta prilagoditi ili potpuno odbaciti. Ovaj aspekt je posebno bitan kada su u pitanju azijske države. Jedno društvo ne postaje moderno samo ako prati tehničke i tehnološke trendove, već se zajedno sa time menja i ideologija jednog naroda, i to nikako drugačije do primanjem stranih uticaja.

Sam Japan je sa ovim procesom usvajanja i prilagođavanja tuđih ideja imao višemilenijsko iskustvo.Japan je tokom istorije usvajao mnoge ideje koje su dolazile iz drugih zemalja, ali je uvek te ideje prilagođavao svojim potrebama. Ideje su se na taj način ponekad toliko menjale da se gubio trag odakle su one došle i u potpunosti bi se stapale sa japanskom tradicijom.

Skoro bilo koja azijska država ima bogatu kulturu i, prilikom prelaska u moderno društvo, suočava se sa većim problemima nego što bi to bio slučaj sa nekom državom sa Zapada, a prvenstveno se misli na težnje da se očuva sopstvena kultura. Japan danas jeste jedna od najrazvijenijih država sveta. Po nekim dostignućima je i najrazvijenija. Stoga ono što od njega mogu naučiti mnoge druge države je kako sačuvati svoju tradiciju u tom moru noviteta i prilagođavanja surovim uslovima ostatka sveta.

\section{Istorijski preduslovi: period Tokugava}

Kao što je već napomenuto, na samom početku sedamnaestog 
veka, Togava Iejasu je uveo Japan u samoizolaciju i time prekinuo sve kontakte između Japana i ostatka sveta. Sem za retke vojskovođe ili zvaničnike koji su uspeli da uspostave kontakt sa Zapadom, može se reći da je ova izolacija bila potpuna. Ovaj proces samoizolacije je u mnogome odredio budućnost Japana i to na jedan vrlo pasivan način, pošto posedice nisu bile odmah sagledive i pošto je ova izolacija trajala nešto više od dva i po veka. Ovaj period i danas pokreće dosta rasprava vezano za to koliko je dobra doneo Japanu, ali kako ništa na svetu nije crno - belo, može se reći da je imao i loših i dobrih strana. Loša strana je svakako nedostatak komunikacije sa ostatkom sveta i izuzetno zaostajanje u odnosu na Zapad. Dobra strana ima više činioca.

Ako pogledamo šta se događalo sa drugim državama Azije u periodu između sedamnaestog i devetnaestog veka - Opijumski ratovi u osamaestom veku u Kini, okupacija Indije od strane Britanaca, takođe u osamnaestom veku, i okupacija drugih delova istočnog dela Azije - događaji su koji su promenili tokove istorije ovog dela sveta. Japan je, međutim, ostao izvan svega toga. Nije dolazio u kontakt sa stranicima, nije bio okupiran u tom periodu, nije dolazilo do odnošenja kapitala iz Japana i japanski narod nije sticao sliku o strancima kao o varvarima, kao što je bio slučaj sa ostatkom Azije. Geografska izolovanost je ovome samo dodatno išla u prilog.

Tokom celog perioda izolacije, japansko društvo je imalo dovoljno vremena i prostora da se okrene samo sebi i da počne da rešava svoje probleme. Priroda novog perioda koji je počeo u Japanu - perioda Tokugava, sama je po sebi donela dosta promena. Politika koju su vodili vladari ovog perioda je bila veoma produktivna za mnoge aspekte društva, iako to svakako nije bio njihov primarni cilj. Ta politika je uključivala agrarne reforme, politiku sankin kotai itd. Na primer, prema sistemu sankin kotai feudalni gospodari su morali da se sele na svakih godinu - dve i da provode izvesno vreme $u$ prestonici, koja pak nije bila njihovo stalno prebivalište te je njima bilo nemoguće da organizuju pobune protiv vlasti iz jednog prostog razloga - nisu za to imali dovoljno vremena, a ponajviše dovoljno novca.

Naredba po kojoj trebalo da feudalni gospodari periodično borave u prestonici je takođe jako bitna iz infrastrukturnih i ekonomskih razloga. Da bi se vojskovođe selile, građeni su putevi. Duž tih puteva su polako nicale kafane i krčme gde bi svi oni koji su tuda prolazili mogli da svrate 
i prenoće. A upravo to je bio izvor kapitala u svim tim objektima. Mreža puteva se polako širila, a dobri i planski pravljeni putevi su mogli da znače samo jedno: dobar osnov za komunikaciju unutar države i ostvaren preduslov za uspešnu trgovinu.

U društvu je takođe dolazilo do promena. Došlo je do klasnih promena, odnosno, bolje rečeno, do preokreta među klasama. Samuraji više nisu bili bogati kao pre i pojavom prvih štamparskih presa polako se širila pismenost među običnim narodom.

$U$ toku perioda Tokugava bilo je onih željnih promena, dobro upoznatih sa napretkom Zapada, i samim tim svesnih činjenice koliko je Japan nazadan. Ali bilo je i onih koji su imali konzervativne poglede na reforme i koji su smatrali da ništa ne treba menjati. Takođe, bilo je i Japanaca koji su uspevali da izađu iz zemlje i da odu u inostranstvo da steknu nova znanja i donesu ih u Japan.

Vladu u novoj eri Meiđi formirali su samuraji niže klase, iz oblasti Sacuma (današnja prefektura Kagošima) i iz oblasti Ćošu (današnja prefektura Jamagući). Iz ovih oblasti krenuo je najveći podsticaj za promenama i za zbacivanje vlasti šoguna i uspostavljanje nove vladavine. Slogani nove vlade su bili "Civilizacija i prosvetljenje", "Obogatiti zemlju i ojačati vojsku", kao i "Industrijalizacija". Nova vlada tražila je model u zapadnim zemljama. Uvođenjem novih modernih društvenih i ekonomskih sistema, podržavali su politiku koja će odbaciti stare zastarele ideje i pretvoriti Japan u modernu državu. U okviru ovih planova za reformama bilo je uključeno i obrazovanje.

\section{Društveni i politički preduslovi}

Koncept moderne države se naravno menjao kroz istoriju. Modernizacija predstavlja napredak $u$ društvu, praćenje noviteta, organizaciju vlasti, veću individualnoj slobodu i širim prava građana. Ako se uzme u obzir da imamo razne kriterijume po osnovu kojih je jedna država moderna, možemo reći da je Japan krenuo sa modernizovanjem već reformom Taika (7. vek), koja je imala visoke ciljeve, ali ne i osnov za njihovo ostvarenje.Državni vrh je bio spremniji da reforme iznese u periodu posle restauracije Meiđi, u čemu je pomogao obrazovani sloj stanovništva.

Restauracija Meiđi, kojom se završio goreopisani period u japans- 
koj istoriji, $u$ isto vreme predstavlja samo početak primene opsežnih reformi u svim aspektima društva i predstavlja ključ modernizacije u Japanu. Možda je diskutabilno da li je ova restauracija izvršena upravo sa državnog vrha, iako se smatra da modernizaciju u Japanu uvek sprovodi država, ali postoji nekoliko činjenica koje mogu pomoći da se ovaj proces bolje razume iz tog svetla. Naime, u japanskom duhu je ukorenjen osećaj da se ne treba protiviti sistemu. U to vreme, to bi značilo direktno se protiviti caru, ili uopšte sistemu vlasti, a upravo to, dakle, nije u duhu Japanaca. Može se reći da je takav odnos prema vlasti ostao i danas. S druge strane, sama vlast ne bi uspešno sprovela reforme da se nije podigao stepen obrazovanja stanovništva. Reformu jednostavno ne bi imao ko da iznese. Treća činjenica je sam naziv: „restauracija“. Naime, naravno, u svim jezicima postoji reč revolucija i već je tada uveliko postojala. Ali ono što se dogodilo u Japanu nije bila revolucija, već restauracija. Nijedna pobuna do koje je došlo u Japanu nije donosila promene u društvu da bi se mogla nazvati revolucijom. To su pre bile pobune za prevlast, nego za neke opsežne promene u društvu. Ovo je osnovna razlika između revolucije i restauracije. Revoluciju pokreće narod, dok restauraciju pokreće država. Revoluciju, takođe, najčešće karakteriše nasilna pobuna naroda, dok sa restauracijom to nije slučaj. U sluačaju Japana, restauracija Meiđi je imala je takođe doprinela tome da se deo političke moći koja je oduzeta šogunu ponovo vrati caru, koji je tokom perioda Tokugava imao samo nominalnu vlast.

Ako uzmemo u obzir sve ove okolnosti, može se zaključiti da je restauracija Meiđi izvršena zajedničkim snagama: državni vrh je svakako pokrenuo ovaj proces, ali je narod bio taj koji je pomogao da ovaj proces uspe. Da nije bilo države da pokrene proces modernizacije koi je započeo posle restauracije Meiđi, vrlo je verovatno da Japan ni dan danas ne bi bio moderna država. S druge strane, da narod nije bio spreman da prihvati ove promene, ovaj pokušaj bi jednostavno propao.

\section{Kulturološki preduslovi}

Sa kulturološke tačke gledišta, u Japanu je, na proces modernizacije, najveći uticaj izvršila priroda konfučijanske religije i odnosi Japana sa inostranstvom. Uprkos samoizolaciji, Japan je i dalje imao kontakte sa Kin- 
om i Holandijom, i ti odnosi su, svaki na svoj način, određivali tok kretanja modernizacije Japana. Odnos prema nauci u Kini je takođe bio veoma važan za naučna saznanja u Japanu sve do kraja Tokugava perioda.

Religija je drugačije oblikovala društvo na Istoku nego na Zapadu. Ona će, takođe, i tamo uvek biti sastavni deo društva, ali se nikada o njoj neće polemisati kao na Zapadu. Lakše se prihvata kao sastavni deo života, ne preispituju se dogme itd. lako nećemo moći duboko da zalazumo u pitanja religije, pomenućemo one aspekte uticaja religije koji su potrebni za bolje razumevanje odnosa Japanaca prema modernizaciji. Konfučijanizam je bitno uticao na stvaranje japanske kulture i promene u njoj. Možda u jednom periodu pomalo zanemarivan, ali i on je u Japanu našao svoje mesto, ravnopravno uz preostale dve najuticajnije religije, budizmom i šintoizmom. Kofučijanizam potiče iz Kine, ali se ova religija razlikuje u Kini i Japanu. Ponovno okretanje ovoj religiji je upravo ono što je pokrenulo japanski narod da polako menja svoje stavove prema obrazovanju i hijerarhiji, i poglede na društvo uopšte. Tako on podstiče unapređivanje obrazovnog i pravnog sistema, kao i opšti kulturni napredak. Takođe, u društvu razvija moralne principe koji će se dugo zadržati.

Pored konfučijanizma, na reforme u Japanu su uticale i reforme $u$ Kini. Administrativni sistem se formirao po uzoru na kineski, a takođe su se otvarale škole i univerziteti na kojima će se školovati budući državni činovnici. U Japanu se polako stvaraju osnove moderne države. Prve odredbe koje su se odnosile na međuljudske odnose i regulisale krivično pravo, donete su na samom početku osmog veka, a važile su praktično sve do jedaestog, a formalno do 1855. godine.

Početkom sedamnaestog veka, i dalje u osamnaestom, počinju da se osnivaju prve nacionalne škole i univerziteti. Specifičnost ovog perioda je što je tokom izolacije u kojoj je Japan bio, komunikacija bila zvanično odobrena samo sa Kinom i Holandijom. Sa Kinom su odnosni bili tradicionalniji i razni vladari, vojskovođe i druge uticajne osobe su slale svoje učenike da se obrazuju u Kinu i da se vrate sa novostečenim znanjima, dok je sa Holandijom bila uspostavljena prvenstveno trgovinska saradnja. I pored toga, ta trgovina se odvijala u strogo kontrolisanim uslovima kao što je to u luci Deđima koja je bila smeštena na jednom isturenom malom ostrvu.

Mana odnosa sa Kinom je ta što je sama Kina pokazivala vrlo malo interesovanja za napredak nauke u svetu. Može se reći da je ova država in- 
Култура и/или наука

telektualno sama sebe ograničila, sve to pod izgovorom očuvanja tradicije. Od sedamnaestog veka, a možda i nešto ranije, nauka u Kini polako zastareva. Kina je uvek bila Japanu uzor u svemu, pa je ovo donekle uticalo i na Japan.

Za razliku od Kine, sa Holandijom je bila sasvim drugačija situacija. Upravo su od Holanđana neki Japanci uspeli da dobiju izvesne knjige i preko toga uvide koliko zaostaju u nauci. Naravno, ovo se dogodilo tek tridesetih godina devetnaestog veka.

\section{Konzervatizam perioda Meiđi}

U svakom društvu koje se nalazi u procesu bilo kakvih većih promena, ima onih koji smatraju promene dobrim potrezom, ali ima i onih koji smatraju da su te iste promene loše za društvo. Takav je slučaj i sa Japanom. Pojava konzervatizma kao odgovora na sveobuhvatne reforme društva nije pojava koja se dogodila samo u Japanu. Pokret konzervatizma je preplavio i skoro celu Evropu, tačnije prvenstveno države u kojima su se događale veće revolucije, na prvom mestu Francusku. Najjednostavnije rečeno, cilj konzervatizma je zadržavanje prethodnog stanja u društvu. S jedne strane, gde god da bi se javio, konzervatizam bi imao isti cilj, dok bi sa druge strane imao specifične karakteristike vezane posebno za datu kulturu i područje.

Kada je Japan u pitanju, konzervatizam se javio kao potreba da se donekle zaštite stare vrednosti na kojma je počivala, a i danas počiva, japanska kultura. Fukuzava Jukići je bio zagovornik promena u Japanu i u mnogome je osuđivao svoje društvo, ali i sagledavao njegove realne nedostatke. $U$ jednom članku ${ }^{1}$ on kaže da dok su Japanci verovali u filozofiju jina i janga i pet elemenata, i verovali da je Zemlja ravna ploča, naučnici na Zapadu su otkrili mnoge druge elemente i bile su im poznate sve činjenice vezane za kretanje planete Zemlje. Dok je Zapad imao železnicu, Japan je imao kočije i teretna kolica. Smatrao je da se Japan ni u čemu ne može porediti sa bilo kojom Zapadnom državom i da je Zapad, za razliku od Japana, mogao da bude ponosan na mnogo šta.

Obrazovanje je bilo prvo koje je trpelo zbog neslaganja između konzervativne i moderne struje. Vodile su se polemike oko toga kako tre-

Craig, 1968. 
ba organizovati obrazovni sistem i školovati mlade. Sam Fukuzava je bio zagovornik novog sistema, ali je svoju decu školovao u tradicionalnoj školi. Konfučijanizam je ovde ponovo odigrao veoma značajnu ulogu. Nudio je odličnu osnovu za stvaranje novog društva. Iz konfučijanizma su preuzeta načela radne etike, poštovanja hijerarhije i nadređenog, ali i otvorene mogućnosti za sve koje bi napredovali po zasluzi i ni po čemu drugom. Na ovaj način, jedno veoma tradicionalno društvo uspelo je da implementira Zapadnu ideju modernog društva.

Tradicionalni koncept porodice je, takođe, imao i dobrih i loših strana. $U$ jednu ruku, kolektivizam, koji je toliko bitan u japanskom društvu, upravo je u porodici sticao svoje korene. Pored dobrih strana kolektivizma, mnogi su smatrali da je upravo taj duh usporavao individualno napredovanje. $S$ druge strane, iz porodice su se nosile vrline kao što su poštovanje nadređenog, požrtvovanost, čast i poštenje, koje su našle svoju primenu i korist i na nivou šireg društva.

Za nekoga ko potiče sa Zapada, koncept moderne države se verovatno donekle podudara sa konceptom demokratske države, odnosno demokratije. Reč koja u japanskom jeziku označava demokratiju je minsei (民生), što u bukvalnom prevodu znači vladavina naroda. Ovaj izraz najbliže oslikava japanski stav prema demokratiji. Međutim, u slučaju Japana, ne može se u potpunosti reći da se iste stvari podrazumevaju pod tim terminom. Sa Zapada su dolazili razni stavovi i pogledi na društvo koji jednostavno nisu mogli da naiđu na dobrodošlicu u jednom toliko tradicionalnom društvu. Osnovna ideja moderne demokratije je, na primer, da se svi u društvu posmatraju kao jednaki i da svi imaju podjednake šanse za napredovanje (kroz rad, obrazovanje itd.). Uvođenjem meritokratije jeste svima omogućeno napredovanje, ali se car i dalje poštovao kao vrhovni sveštenik i direktan potomak japanskog božanstva. Ova činjenica nije ostavljala prostora za jednakost među ljudima, jer nije svako mogao da postane car.

\section{Stvaranje modernog Japana}

Nije veliki problem pogledati Japan sad i videti jednu od najmodernijih država sveta, ako ne i najmoderniju. Posle restauracije Meiđi ovu 
državu su čekale jako ozbiljne reforme svakog aspekta društva, a Japanci su te reforme sproveli jako uspešno.

Za uspešno sproveden proces modernizacije Japana zaslužno je više faktora, a rezervisan stav Japanaca prema inostranstvu i visok nivo nacionalne svesti su odigrali najveću ulogu. Ova dva faktora su dala glavnu karakteristiku celom procesu „hvatanja koraka sa Zapadom“. Naime, Japanci su imali jedinstven pristup usvajanju noviteta. Oni nikada nisu dozvoljavali da stranci direktno utiču na bilo koji proces u Japanu, te nijedna ideja sa Zapada nije bila prihvaćena a da prethodno nije dobro razmotreno šta je najbolje prihvatiti od te ideje, a šta treba odbaciti. Na ovaj način Japanci su uspevali da sačuvaju svoju tradiciju od uticaja drugih, ali i, jako često, da modifikuju strane ideje do te mere, da se na kraju činilo kao da su one oduvek bile sastavni deo japanske kulture.

Dakle, već od sredine devetnaestog veka, koliko god da je vlast bila nepopustljiva u otvaranju ka svetu, s jedne strane, svest o tehničkom, tehnološkom i svakom drugom nazadovanju je postajala očigledna. Ipak, nije bila toliko bitna nazadnost u tehnološkom razvoju, već to šta je ta nazadnost značila, prvenstveno vojno slabu državu.

Prvo što su Japanci shvatili je da ne bi bili sposobni da se suprotstave bilo kojoj stranoj sili u slučaju napada. Takođe im je bilo poznato šta se dogodilo Kini posle Opijumskih ratova. Zbog svega toga, kao i zbog toga što su od avgusta prethodne godine u njihove luke bili ukotvljeni Crni brodovi komodora Perija, februara 1854. godine Japanci ipak odlučuju da otvore luke za trgovinu sa Amerikancima. Ovo predstavlja samo mali početak.

Godine 1871. u inostranstvo je poslata misija Ivakura. Ovo predstavlja prvo napuštanje zemlje radi odlaska u inostranstvo zvaničnika u većem broju posle dva i po veka. Primarni cilj ove misije jeste bio u nekim granicama uspostavljanje prijateljskih odnosa sa Velikom Britanijom, Rusijom, Nemačkom i Amerikom, ali i da se uvidi situacija u Evropi i uveri u njen napredak.

Što se nauke tiče, ona se u Japanu, sve do kraja devetnaestog veka, zasnivala na drevnim kineskim spisima. Kako Kinezi sami nisu bili voljni da unapređuju svoju nauku, a Japanci su gotovo samo od njih usvajali nova znanja, tako su Japanci ostajali ograničeni na te stare spise. Prvi noviteti sa Zapada koji su stigli, kada je nauka pitanju, bili su medicinski udžbenici, i to oni iz anatomije. Preko crteža koje su dobili iz Holandije, odnosno 
anatomskog atlasa, Japanci su u prvi mah uvideli da se njihovi i novi spisi poprilično razlikuju. Ali su Japanci ipak uvideli su da su holandski spisi bili tačni i da su se poklapali sa stvarnom anatomijom čoveka. Ovo ih je uverilo koliko su oni zapravo u zaostatku sa svetom. Danonoćnim naporima su se trudili da prevedu anatomski rečnik i dovijali se na razne načine.

Stoga su za vreme restauracije, Japanci takođe slali ljude da uče u inostranstvu, da bi se oni posle vraćali i stečena znanja prenosili svom narodu.Takođe, oni bi angažovali strane stručnjake u Japanu, kojima bi obezbeđivali najbolje uslove za rad i koji bi prenosili svoja znanja Japancima, a nakon toga bi se vraćali u svoje zemlje. U mnogim državama koje su bile u stanju u kom je Japan bio tada, mnogi se ne bi vratili u svoju državu posle obuke $u$ inostranstvu, ali to nije slučaj sa Japancima.

Model za reforme je, tako, preuzet iz inostranstva. Ustav je napravljen po uzoru na pruski, univerziteti su organizovani po uzoru na američke, osnovne škole po uzoru na francuske, železnica je preuzeta od Velike Britanije, krivični zakonik od Francuske, a građanski od Nemačke. Obrazovanje je postalo obavezno za sve već u prvoj deceniji dvadesetog veka. Žene su tridesetih godina dobile pravo da budu politički aktivne, a posle Drugog svetskog rata dobile su i pravo glasa. Sem toga, na nivou države je uspešno izvršeno zvanično ukidanje privilegija po osnovu porekla i materijalnog statusa, odnosno uvodena je meritokratija, a postignut je i značajan razvoj industrije. Ipak, moglo bi biti diskutabilno da li su Japanci našli najbolje rešenje za sva pitanja. Naime, svakako da ništa nije idealno. Nije napravljen idealni sistem obrazovanja, ekonomija je bila pod senkom monopolizma, imali su poteškoća u oblikovanju zakonodavstva, ali neverovatno brz napredak društva se ne može nikako osporiti.

\section{Reforme obrazovnog sistema}

Čak i u periodu vladavine Tokugava, obrazovanje koje se sticalo u Japanu nije bilo zanemarljivo. Proučavali su se kineski klasici, učila se kineska istorija, osnivale su se privatne "akademije", a pri kraju perioda Tokugava, u Japanu se uspostavljaju Holandske studije (Rangaku). Holandske škole su u Japan stigle preko Nagasakija u Kjušuu, gde je Holanđanima bilo dozvoljeno da pristanu. U ovom trenutku, ovo je bio jedini izvor znanja sa Za- 
pada, koji se širio Japanom. Holandske škole nisu bile dostupne običnom svetu. Običan svet se obrazovao u terakojama, gde je sticao veštine koje su bile potrebne za što bolji svakodnevni život.

Ipak, sistem obrazovanja u ovom periodu imao je dosta mana. Obrazovanje nije bilo jedinstveno za sve. Čak nije ni trajalo isti period. Priliku da se najbolje obrazuju su imali oni koji su bili na višem društvenom položaju, pa je i njihovo obrazovanje najduže trajalo. Metode učenja takođe nisu bile jedinstvene, ali ni metod ispitivanja, a samim tim i napredovanja. Ovo su sve karakteristike koje bi se mogle naći u dobro osmišljenom modernom obrazovnom sistemu, ali su nedostajale japanskom obrazovnom sistemu.

Ono što je Japanu trebalo je organizovano sprovođenje nastave i donošenja odluka. Ovaj problem polako počinje da se rešava već na samom početku perioda Meiđi. Osniva se Ministarstvo za obrazovanje u okviru vlade (1871) i kreće se sa ispitivanjem stranih škola, da bi se na osnovu toga odlučilo šta će se prihvatiti u novom sistemu školovanja. Već naredne godine (1872) doneti su prvi propisi o sistematizaciji obrazovanja.

Školski sistem koji je formiran sastojao se od tri nivoa: osnovna škola, srednja škola i univerzitetsko obrazovanje. Amerika je bila model za ovaj školski sistem. Francuska je bila model za centralizovani sistem obrazovne administracije na oblasnom nivou.

Cela država je bila podeljena na 8 univerzitetskih oblasti, od kojih je svaka podeljena na 32 oblasti srednjih škola, a svaka ova oblast je bila dalje podeljena na 210 osnovnih škola. U svakoj oblasti je trebalo uspostaviti školu odgovarajućeg tipa. Na ovaj način, u Japanu je postojalo 8 univerziteta, 256 srednjih škola i preko 50.000 osnovnih škola. Ako se ume u obzir vreme u kome je dolazilo do ovih reformi, ovo je bio veoma ambiciozan plan koji je trebalo ostvariti.

Osnovna škola se delila na dva perioda od po 4 godine ( 8 godina ukupno) i generalno, sva deca su bila u obavezi da prisustvuju nastavi, bez obzira na pol, porodično poreklo ili društveni status. Učitelji koji su radili u osnovnim školama su u velikom broju bili terakoja učitelji, ili privatni učitelji, koji su prelazili, po potrebi, da rade u ovim školama. Većina feudalnih škola bilo je reorganizovano u državne osnovne škole.

Na samom početku perioda Meiđi, Japanci su imali dve politike: politiku zapošljavanja stranih predavača, koji su predavali na stranom jeziku, kao i slanja Japanaca koji bi se obrazovali u inostranstvu i koji bi po povrat- 
ku u Japan, zamenili strane predavače. Ovo je bio veoma skup poduhvat, jer su plate stranih predavača bile jako visoke, pa se tako celokupna realizacija oslanjala na lolakalno finansiranje, porez stanovništva u školskim oblastima i na školarine.

Kada je reč o sadržni knjiga za osnovnu školu, u na samom početku reformi, knjige su bile kopije američkih udžbenika. Ovo je predstavljalo problem, jer je narod već navikao na tradicionalne sadržaje terakoja škola, koji više nisu bili zastupljeni. Takođe, osnovno školovanje je sada trajalo 8 godina, što je znatno duže od prethodnog standarda trajanja obrazovanja oko 2 godine. Većina porodica se i dalje izdržavala od poljoprivrede, pa im je bila neophodna sva raspoloživa radna snaga u porodici. Vlada je pokušala da podstakne upisivanje u školu, uz objašnjenja dobrih strana obrazovanja, ali, 10 godina nakon uvođenja novih propisa o obrazovanju (1883), zvanična stopa upisivanja je bila 47\%. Ovo je u realnosti bilo još i niže, jer se, uprkos obaveznom obrazovanju za dečake i devojčice, upisivalo tek 30\% devojčica. Takođe, veliki broj polaznika je odustajao pre nego što bi završio neophodnih 8 godina obrazovanja, a narod se bunio protiv poreza na školovanje.

Jedan od koraka u modernizovanju obrazovnog sistema je bilo pozajmljivanje metoda za organizovanje nastave iz Sjedinjenih država. Vlada je pozvala 1872. godine, profesora Mariona Skota iz Sjedinjenih država, kao stručnjaka za obrazovanje, čije su metode iskoristili za uređivanje osnovnih škola. U univerzitetskim gradovima su otvarane škole, koje su nudile obuku u trajanju od 1-3 meseca, gde su svi koji su završili osnovnu školu mogli da steknu uvid u nove metode predavanja. Na ovaj način, vlada je pokušala da se bori sa nedostatkom broja nastavnog kadra.

Ideje koje je vlada imala nameru da sprovede otvaranjem 8 univerziteta, u stvarnosti su teško mogle da se sprovedu. Do 1877. godine, otvoren je samo jedan univerzitet - Univerzitet u Tokiju. Vlada je 1879. godine izdala novo naređenje o obrazovanju, koje je zamenilo prethodno. PO novim pravilima, organizovanje školstva prebačeno je na nadležnost opština (umesto dosadašnje oblasne nadležnosti) i data im je sloboda da kreiraju nastavni plan u skladu sa realnim potrebama u svojim opštinama. Vreme obaveznog školovanja se skratilo sa 8 godina na bar 16 meseci u toku celokupnog trajanja školovanja. Međutim, upisna dinamika se još više pogoršala, pa je tako vlada 1890. godine dopunila propis iz 1879. 
godine, kojim sada nalaže obavezno prisustvo tokom 16 ili više nedelja godišnje, u periodu od 3 godine.

Takođe, negde krajem 1870. godine, došlo je do sukoba ideologija. Naravno, postojale su dve struje. Oni koji su bili protiv modernizacije su isticali koliko je došlo do pada morala u Japanu i zalagali su se za tradicionalne vrednosti, čast i poštenje. S druge strane oni koji su bili za modernizaciju države generalno, želeli su i moderni sistem obrazovanja, koji se više zasnivao na prosvećenoj politici, koja je i pokrenula Restauraciju. Zagovornici obe ideologije su imali problema da se dogovore u kom pravcu će ići dalje obrazovanje.

U ovom periodu dolazi od organizovanih pokreta učitelja koji su se borili za svoje ideje i koji su smatrali da bi sistem obrazovanja trebalo osavremeniti. Oni su se takođe protivili jakom političkom monopolu i njihovom nametanju volje. Vlada je shvatila da bi ipak trebalo da ojača svoju kontrolu nad obrazovanjem i nad nastavnim sadržajem, kao i da uspostavi bolju kontrolu nad delima i rečima predavača; pa se tako u ovom trenutku priklonila konzervativnoj, konfučijanskoj ideologiji. Prema ovome, 1880. godine je izdato novo naređenje, po kome su moral, čitanje, pisanje, matematika, istorija i geografija određeni kao predmeti koji će se predavati u osnovnoj školi, gde će "moral" kao predmet imati najvažniju poziciju.

U Japanu se 1885. godine, centralni birokratski sistem (čija je organizacija pozajmljena od Kine), menja sistemom kabineta, pa je tako Ito Hirobumi postavljen za prvog japanskog ministra. Kada je na red došlo obrazovanje, Ito se nije okrenuo ka Velikoj Britaniji ili Francuskoj, već Pruskoj, za koju je smatrao da je u sličnoj poziciji kada je u pitanju reforma obrazovanja, ali i društva uopšteno gledano.

Kao prvi ministar obrazovanja imenovan je Mori Arinori, prosvećeni birokrata sa diplomatskim iskustvom iz Velike Britanije i iz Amerike. Upravo je on postavio nove okvire obrazovanja za koje je smatrao da predstavljaju osnov svakog uspešnog društva i bitan faktor razvoja. Po njegovim okvirima, školovanje je podeljeno u četiri faze: osnovna škola, srednja škola, klasična škola i univerzitet. Svaka ova faza je imala svoj zaseban cilj u zavisnosti od potreba društva i polaznika. Univerzitet je bio definisan kao mesto gde će se izučavati umetnost i nauka, koji su potrebni za društveni napredak. Univerzitet je imao dosta akademske slobode, jer je predstavljao instituciju gde će se takođe školovati kadrovi u skladu sa novim zahtevi- 
ma i potrebama, kao i učitelji koji će dalje prenositi svoja znanja. Na Carskom univerzitetu su se izučavale nauke, odnosno formirali su se smerovi koji su u tom trenutku odgovarali ministarskim kabinetima. Tako su kreirani sledeći odseci, odnosno fakulteti: Pravni fakultet, Šumarski fakultet, Poljoprivredni fakultet, Trgovinski fakultet. Svi ovi fakulteti su imali odgovarajuća ministarstva (zbog čijih su potreba i nastali), a pripadali su Carskom univerzitetu.

Srednje škole su bile institucije u kojima je trebalo pripremiti učenike za Carski univezitet. S druge strane, osnovne škole su imale karakter obrazovnih ustanova koje su bile zadužene za podizanje dece i učenje da postanu lojalni podređenici Cara. S organizacione tačke gledišta, osnova škola se delila u dva nivoa, gde je prve četiri godine bilo nametnuto kao obavezno svim građanima. Osnova škola, koja je sprovodila ovu nametnutu dužnost je prvi primer zakonskog obaveznog obrazovanja u Japanu. Međutim, ukoliko bi to uslovi nalagali, postojala je mogućnost odobravanja posebne dozvole za trogodišnje pojednostavljeno obavezno obrazovanje.

Ministar Mori je u obrazovanju u klasičnim školama takođe video priliku da se oblikuje japanski duh. Glavni moto koji je trebalo da predavači prenesu studentima je bio "Poslušnost, poverenje dostojanstvo." Od njih se očekivala poslušnost, povinovanje nadređenom, ali, predavači su takođe morali da pokazuju naklonost prema svom poslu i određenu naklonost prema studentima. Pored klasičnog učenja, oni su bili i fizički obučavani kroz razne programe vojnog tipa. Živeli su zajedno u studentskim domovima, što je podsticalo kolektivni duh. Dobijali su mnoge privilegije, uključujući oslobađanje vojne službe i besplatne školarine i besplatne hrane, a takođe su dobijali novac i za odeću i razne troškove i druge stvari. Zauzvrat, bili su u obavezi da rade kao učitelji određeni period odmah nakon diplomiranja. Ministar Mori je na ovaj način želeo da uradi dve stvari: da modernizuje japansko obrazovanje, s jedne strade, ali i da podstakne kolektivni duh i osećaj nacionalnog jedinstva, s druge strane.

Industrijski razvoj Japana još je jedan od faktora koji je uticao na oblikovanje obrazovanja. Sa sve većim napretkom, dolazilo je i do sve veće potrebe za kadrovima obrazovanim za rad u granama teške i lake industrije. Ovaj problem je rešen uvođenjem dvojnog sistema obrazovanja. Naime, dok je Carski univerzitet i dalje ostao mesto gde su svi studenti 
dobijali potrebna obrazovanja iz društvenih i prirodnih nauka, otvarali su se fakulteti na kojima se moglo u učiti i pravo, trgovina, medicina, farmacija, ali i gde su se osposobljavali budići tehnološki inženjeri. Spektar nauka bio je veoma širok, jer pored ispunjavanja potreba za tehnički obrazovanim kadrovima, Japan i dalje nastavlja politiku modernizovanja svoje države i uvođenja na svoje fakultete svih onih disciplina koje su bile popularne i na Zapadu. Ovakav vid obrazovanja (i na Carskom i na specijalizovanim fakultetima) regulisan je zakonskim aktom iz 1903. godine

Do 1880. godine, stopa upisa u škole nije bila znatno veća. Međutim, već 1890. godine, stopa polaznika u školu je negde oko 69\%. Trogodišnje pojednostavljeno školovanje je ukinuto 1900. godine, a obavezno školovanje je produženo sa 4 na 6 godina. Ako se uzeme u obzir da je stopa upisa u školu i dalje rasla, dolazi se do zaključka da je već početkom dvadesetog veka stopa nepismenosti u Japanu skoro svedena na nulu.

Podstaknuti najnovijim ekonomsko-društvenim događanjima u svetu (Rusko-japanski rat, 1904-05; Prvi svetski rat, 1914-1918), Japanci su počeli da organizuju svoje univerzitete još sistematičnije. Za razliku od dosadašnjih sveobuhvatnih sistema studiranja, počeli su da otvaraju unvierzitete i fakultete koji su se specijalizovali za neke određene predmete. Tako je otvoren prvi tokijski Trgovački fakultet, kao državna ustanova, zajedno sa univerzitetima Vaseda, Keio, Meiđi, Hosei i Sošiša. Njihov status se iz fakulteta promenio vrlo brzo u univerzitete.

Dvadesetih i tridesetih godina dvadesetog veka na obrazovanje u Japanu uveliko utiče militarizam i struje koje se protive demokratskim trendovima. Dvadesetih godina u svetu dolazi od ekonomske krize, čije su se posledice osetile i u Japanu. Vlada zauzima veću kontrolu nad gradivom koje se uči u školama, osnovne škole postaju nacionalne škole (1941), a oslobađanje studenata od dužnosti vojnog roka se ukida. Militarizam je prisutan u svim nivoima obrazovanja, gde se studenti obučavaju ili da proizvode zalihe hrane ili da prave vojnu opremu.

Posle Drugog svetskog rata, Japan je primoran da zauzme drugačiji stav kada je u pitanju organizovanje obrazovnog sistema. Do ovoga dolazi iz dva razloga. Prvi je njihova, i dalje prisutna, želja da sustignu Zapad na svim frontovima. Drugi razlog je malo drugačije prirode i on uključuje američke okupacione snage u Japanu. Zajedno vojnim snagama, u Japan dolazi i američka Obrazovna misija, koja zajedno sa japans- 
kim stručnjacima preuređuje njihov sistem obrazovanja. Prve promene, koje su i najočiglednije su ukidanje naziva "nacionalne škole", izbacivanje nacionalističkih i militarističkih tekstova iz udženika, i sveobuhvatno prilagođavanje nastavnog plana sa planom na Zapadu. Ukinute su klasične škole. Uveden je sistem osnovne, više i niže srednje škole i fakulteta (6-33-4). Obavezno obrazovanje je takođe prošireno na 9 obaveznih godina. Osnovani su odbori na nivou prefektura i opština.

\section{Uloga obrazovanja kao preduslova ekonomskog razvoja}

Moderni Japan pokazuje mnogo karakteristika konfucijanskog društva koje dobro funkcioniše. To se ogleda u:

1. Poštovanju prema starijima

2. Lojalnosti prema kompaniji (doživotno zaposlenje)

3. Sempai - kohai sistem (lojalnost i posvećenost)

4. Nižoj stopi kriminala nego na Zapadu (poverenje, poštovanje, poštenje). Ako izgubite nešto u Japanu ili zaboravite novčanik, u većini slučajeva će vam ga vratiti u restoranu ili ćete ga naći u birou za zaboravljene stvari na stanici.

5. Stabilnoj strukturi porodice (niže stope razvoda u odnosu na zemlje Zapada)

6. Jakom obrazovnom sistemu (prijemni ispiti veoma su teški)

7. Socijalne devijacije su manje nego u zemljama Zapada (sigurnije ulice, bolje škole)

8. U japanskom jeziku postoje brojni izrazi i oblici kojima se izražava poštovanje. Japanci su veoma rezervisani prema drugim ljudima i retki su javni ispadi na javnim mestima.

Opšte javno obrazovanje ima ulogu u pripremanju omladine za osnovna akademska znanja i za trgovačke veštine. Pripravnički staž izgrađuje potrebne trgovačke veštine. U slučaju da se skromne količine novca i zemlje udruže sa malom količinog znanja o poljoprivredi u zemlji sa umerenom klimom, stanovnici ce biti osuđeni na goli život. Obrazovanje za žene je omogućeno je smanjenjem veličine porodice - što je važan razlog suzbijanja siromaštva. Ako društvo želi da prevaziđe siromštvo i ne bude svedeno na golu egzistenciju, potreban je velik broj pojedinaca koji poseduju 
delimično obrazovanje koje se tiče različitih veština koje su potrebne da bi se izgradila i očuvala infrastruktura društva u razvoju: izgradnja trgovine, sistema vodovoda, struje, poljoprivreda i razvijanje mehaničkih veština.

Prva osoba koja se ozbiljno bavila konceptom države razvoja je Čalmers Džonson. U svojoj knjizi MITI and the Japanese Miracle napisao je2:

U državama koje su se kasno industrijalizovale, sama država je upravljala industrijalizacijom, i preuzela funkcije razvoja. Ova dve različite orijentacije, nasuprot privatnim ekonomskim aktivnostima: orijentacija nadzora i orijentacija razvoja stvorile su dva različita tipa odnosa između trgovine i vlade. Sjedninjene države su dobar primer za državu u kojoj dominira orijentacija nadzora, dok je Japan dobar primer za državu u kojoj dominira orijentacija razvoja.

U slučaju Japana, vlada poseduje mali deo industrije, ali elita vladine birokratije strogo vodi i ograničava privatni sektor. Ovakvu vladavinu birokratske elite ne čine samo izabrani zvaničnici i, prema tome, manje utiču na korporacije i radničku klasu kroz političke procese. Argumet za ovaj način posmatranja je da ministarstva u vladi treba da imaju slobodu da razvijaju plansku ekonomiju i dugoročno gledaju na nacionalne interese i da se izbegne da su njihove ekonomske polise kompromitovane od strane kompanija ili radničke klase i njihovim uskim gledištima i kratkotrajnim rešenjima.

Istorija obrazovanja u Japanu

Osnovnim školama u obrazovnom smislu prethode vrtići i centri za dnevni boravak. Javni i privatni centri za dnevni boravak prihvataju decu uzrasta od jedne do pet godina starosti. Programi za decu od 3-5 godina su slični su onima u vrtićima. Obrazovni pristup u vrtićima varira od neogranizovanog okruženja koje naglašava igru do organizovanog okruženja koje se fokusira da deca prođu prijemne ispite za privatne osnovne škole.

Učenje čitanja i pisanja postoji u nekom obliku od kako se uvelo kinesko pismo i budizam u 6. veku. Godine 701. Taiho vlada je osnovala skore za decu viših slojeva i u glavnom gradu i u unutrašnjosti. Počekom

2 Johnson, Chalmers 1982. MITI and the Japanese Miracle. Stanford, California: Stanford University Press 
Kamakura perioda (1185-1333) porastao je broj dece samuraja koja su imala formalno obrazovanje, tek je za vreme 250 godina mira u Edo periodu (1600-1868) takvo obrazovanje postalo široko rasprostranjeno i među elitomi među običnim ljudima.

Obrazovanje u Edo periodu se baziralo na konfucijanstvo koje je naglašavalo učenje napamet i proučavanje kineskih klasika. Razvijaju se dva osnovna tipa škole. Prvi tip je obrazovanje u oblastima (hanko)koje je postojalo u više od 200 oblasti do kraja Edo perioda i omogućulo obrazovanje prvenstveno za decu iz samurajske klase. Drugi tip su terakoja skole, koje su primale decu obicnih ljudi i samuraja i naglašavale moralni trening i učenje čitanja, pisanja i aritmetike. Terakuja škole su obično vodili jedan učitelj i bračni par i postojalo je hiljade ovakvih školi do kraja Edo perioda.

Stepen pismenosti u vreme propasti Tokugava šogunata 1868 je bio 40 procenata, što se bilo više nego u većini Zapadnih zemalja tog perioda. Bez ovakvog temelja obrazovanja, brza modernizacija koje je postignuta narednih godina ne bi bila moguća.

Političari Meiđi perioda želeli su razvoji u uvedu obrazovni sistem koji bi Japanu omogućio da se ujedini i da dovede ga na nivo zapadnog razvoja. Njihov sistem je imao tri nivoa: osnovnu školu, srednju školu i fakultet. I dečaci i devočice su morali da pohađaju osnovnu školu.

Drugi svetski rat je doneo promene u obrazovnom sistemu Japana. Uz pomoć okupacionih snaga, usvojena su dva zakona, Osnovni zakon o obrazovanju i Zakono o obrazovanju u školama. Zakon o obrazovanju u školama definiše sistem koji je i dalje na snazi u Japanu.: šest godina osnovne škole $3+3$ godine srednje i dve ili četiri godine fakulteta. Pohađanje osnovne škole i prve tri godine je obavezno.

Istorija pismenosti u Japanu datira s kraja šestog veka kada su kineski ideogrami uvedeni na dvor Jamato. Strane civilizacije su često donosile nove ideje za razvoj japanske kulture.

Učenje o Kini je započeto između šestog i devetog veka. Zajedno sa dolaskom budizma, došao je i kineski način pisanja i književna tradicija, kako i konfucijanstvo. Do devetog veka, Heian-kjo (današnji Kjoto) koji je tada bio prestonica, imao je pet institucija višeg obrazovanja. Tokom Heian perioda su dvor i plemstvo osnovali više škola. U srednjovekovnom periodu (1185-1600) manastiri zen budizma su bili naročito važni centri 
učenja i Ašikaga gako je cvetala je u petnaestom veku kao centar višeg obrazovanja. Mnogi učenici su dolazili iz svih delova Japana da proučavaju konfucijanizam, Ji Đing i kinesku medicinu

U 16. veku i ranom 17. veku, Japan je doživeo intenzivni kontakt sa velikim evropskim silama. Jezuitski misionari i portugalski trgovci su propovedali hrišćanstvo i otvorili nekoliko religijskih škola. Učenici u Japanu su počeli da uče latinski i klasičnu muziku Zapada uz svoj jezik.

Japan je ujedinjen pod režimom Tokugave i neokonfucijanska akademija, Jušima Seido u Edu je bila glavna obrazovna ustanova u zemlji. Na njenom čelu je bio Daigaku-no-kami koji je bio šef obuke za birokrate šogunata. Kansei edikt je uveo neo- kofučijanizam kao zvaničnu filozofiju u Japanu. Do 1640. godine stranci su proterani iz Japana, hrišćanstvo je proterano i svi kontakti sa strancima su zabranjeni. Zemlja je ušla u period izolacije i mira koji je trajao 200 godina. Na početku Tokugava perioda, samo je malo običnih ljudi znalo da čita i piše. Do kraja Tokugava perioda školovanje se proširilo. Obrazovanje u Tokugava periodu ima veliku zaostavštinu: značajno je porasla pismenost, uvedena je meritokratija (oblik oligarhijske vladavine u kojoj je vlast ograničena na osobe koje se od ostatka stanovništva razlikuju superiornim fizičkim ili mentalnim sposobnostima, odnosno zaslugama za državu, društvo ili organizaciju) i stavljen je naglasak na diciplinu i razvijanje takmičarskog duha. Pod Meiđi režimom ovaj osnov će ubrzati tranziciju od feudalne zemlje do moderne nacije.

Jedna od stvari koje su impresionirale Evropljane koji su došli u Japan na kraju Edo perioda bila je da su Japanci bili veoma obrazovani i da je postojala popularna kultura za koju se tada verovalo da ne može postojati bez industrijske revolucije. Stopa pismenosi je već bila preko $80 \%$ za muškarce.

Za vreme Tokugava perioda se uloga samuraja promenila od ratnika do birokrate i kao posledica toga njihovo formalno obrazovanje i pismenost su proporcijalno rasli. Kodeks samuraja je naglašavao moral i uključivao i učenje vojnih veština i opismenjavanje.

Konfucijanski klasici su učeni napamet i njihovo čitanje i recitovanje je bila uobičajna metoda učenja. Aritmetika i kalifrafija su se takođe učile. Većina samuraja je išla u škole koje su izgrađene u hanovima i do 1868. godine je više od 200 (od 276) hanova imalo škole. Neki samuraji i obični 
ljudi su pohađali privatne škole koje su se često spezijalizovale za japanske predmete ili zapadnu medicinu, modernu vojnu nauku, naoružanje ili ranraku (holandske studije), kako su u to vreme zvale studije o Evropi.

Obrazovanje običnih ljudi je bilo orijentisano na praksu i omogućavalo je osnovnu obuku u čitanju, pisanju i aritmetici, a posebno pažnja se posvećivala učenju kaligrafije i korišćenju računaljke. Veliki deo je nastave je izvođen u školama u hramovima (terakoja) koje su nastale od ranijih budističkih škola. Ove škole više nisu bile religijske ustanove i do 1867. godine se više nisu nalazile u hramovima. Do kraja Tokugava perioda bilo je više do 11.000 ovakvih škola koje su imale oko 750.000 učenika. Terakoja škole su davale prioritet učenju čitanja i pisanja, ali su postojali i drugi predmeti i discipline, kao što su: računanje računjaljkom, istorija i geografija. Devojčice su učile da šiju, čajnu ceremoniju, ikebanu, umetnost i zanate. Časovi su se održavali u privatnim domovima samuraja, budističkih sveštenika i običnih ljudi. Predavači su većinom bili obični ljudi, ali bilo je i budističkih monaha. Administracijom su se bavili sami profesori. Centri popularnog obrazovanja su uglavnom davali obuku iz veština potrebnih za svakodnevni život, dok su terakoja škole nudile viši nivo obrazovanja.

Terakoja škole su bile privatne obrazovne ustanove u kojima su deca običnih ljudi učila da čitaju i pišu. Prva terakoja se pojavila u 17. veku kao nastavak obrazovnih objekata koji su postojali u budističkim hramovima. Do Edo perioda javne obrazovne ustanove su bile samo za decu samuraja i vladarskih porodica, ali, zbog uspona trgovačke klase sredinom Edo perioda, porasla je popularnost terakoja škola i bile su rasprostranjene u velikim gradovima poput Eda i Osake i u seoskim i priobalnim oblastima. Stopa posećenosti terakoja škola je bila $70 \%$ u Edu na kraju 18. i početkom 19. veka. Terakoja škole su zatvorene u Meiđi periodu, kada je vlada donela Naredbu o sistemu obrazovanja 1872. godine i pohađanje javnih škola postalo obavezno kao mera osnovnog obrazovanja za celu populaciju.

Posle 1868. godine nova vlast je pokrenula u Japanu brz proces modernizacije. Političari Meiđi perioda su osnovala javni sistem obrazovanja da pomognu Japanu da uhvati korak sa Zapadom i osnuje modernu naciju. Delegacije kao Ivakura su slate u inostranstvo da proučavaju obrazovne sisteme vodećih zapadnih zemalja. Vratili su se sa idejama decentralizacije, lokalnih školskih odbora i autonomijom nastavnika. Ove ideje i ambiciozni osnovni plan su bili veoma teški za sprovođenje. Posle više pokušaja 
Култура и/или наука

i grešaka, stvoren je novi nacionalni sistem obrazovanja. Dokaz uspeha je da se broj upisanih đaka popeo sa 40 do 50 procenata 1870 na više od $90 \%$ do 1900. godine uprkos jakim javnim protesitima, posebno protiv školarina. Do 1890-ih godina, uprkos jakom preokupacijom zapadnim idejama školstva (posebno američkim), razvio se konzervativniji i tradicionalniji pravac. Naglašavale su se ideje konfucijanstva, posebno one koje su se ticale hijerarhijske prirode ljudskih odnosa, služenja državi, stalnog učenja i morala. Ove ideje ovaploćene su 1890. godine u Carskom proglasu o obrazovanju. Centralizovna je kontola vlade nad obrazovanjem.

U ranom 20. veku obrazovanje se pre svega baziralo na jednakosti i univerzalonosti, ali je bilo višeslojno, selektivno i elitističko. Univerzitetsko obrazovanje je bilo ograničeno na nekoliko carskih univerziteta i nemački uticaj je bio veliki. Tri carska univerziteta su upisivala žene i postojalo je nekoliko ženskih fakulteta, od kojiih su neki bili prestižni, ali su žene imale prilično male mogućnosti za više obrazovanje. Tokom ovog perioda su hrišćanski misionari osnovali nekoliko univerziteta i preuzeli ulogu širenja obrazovnih mogućnosti za žene, posebno na nivou srednjih škola.

Posle 1919. godine je nekoliko privatnih univerzizeta dobilo status javnih ustanova i vlada je priznala programe koje su oni imale. 1920-ih se vratila tradicija liberalnog obrazovanja, naročito na predškolskom nivou. 1930-tih godina je obrazovanje bilo pod jakim uticajem vojske i bilo je nacionalno usmereno pod Sadao Arakijem³.

Za vreme Drugog svetskog rata mnogi japanski studenti su bili aktivni u ratu, posebno zbog toga što su škole bile pretvorene u fabrike. Bombardovanja su uništila mnoge škole. Posle rata su okupacione sile imale mnogo toga da poprave. Okupatori su se usmerili na system obrazovanja. Japanski metodi su bili potpuno drugačiji od metoda Sjedninjenih država: kontrola škola je bila centralizovana, učenje se svodilo na prostu reprodukciju udžbenika bez interakcije između studenta i profesora. Uvedena je manje centralizovana hijerarhija administracije. Roditelji su počeli da glasaju na školskim odborima. Uvedeni su novi udžbenice. Ipak, kad se okupacija završila, vratilo se na veći deo starih metoda.

Do 1945. godine je obrazovni sistem u Japanu bio uništen. Sa porazom je došlo do diskreditovanja predratnih misli. Novi talas inostranih ideja je uveden u toku posleratnog perioda vojne okupacije.

3 Pyle, Kenneth B.1996.The Making of Modern Japan, Lexington: D.C. Heath 
Okupatori i Obrazovna misija SAD-a, započeta 1946. godine su uveli niz promena usmerenih ka demokratizaciji obrazovanja u Japanu: uvedena je 6-3-3 stuktura obrazovanja (šestogodišnja osnovna škola i 3+3 razreda srednje škole) i uvedeno je obavezno pohađanja škole u trajanju 9 godina. Zamenjen je predratni sistem srednjih škola. Nastavni plan i udžbenici u revidirani i nacionalistička stuja je ukinuta i zamenjena društvenim nakukama. Takođe, uvedeni su lokalni školski odbori i osnovan je sindikat profesora.

Ukidanjem elitističkog sistema višeg obrazovanja i porastom broja institucija višeg obrazovanja povećale su se mogućnosti za više obrazovanje. Ovo je omogućeno pre svega otvaranjem fakulteta i brojnih tehničkih institucija, običnih škola i naprednih srednjih škola. Posle povraćaja nacionalnog suvereniteta 1952. godine, Japan je odmah počeo da usvaja neke promene u obrazovanju i da utiče na ideje o obrazovanju i obrazovnoj administaciji. Posleratno Ministarstvo obrazovanja je ponovo uspostavilo veliki deo moći koju je imalo. Školski odbori su izglasavani umesto da budu birani. Struja moralnog obrazovanja je ponovo uspostavljena u izmenjenom obliku,uprkos prvobitnoj brizi da će do dovesti do obnavljanja nacionalizma. Do 1960-tih godina je posleratni oporavak i brzi rast ekonomije doveo do ekspanzije obrazovanja na fakultetskom nivou. Kako su rasla očekivanja da će se poboljšati kvalitet visokog obrazovanja, tako su rasli troškovi. 1960te godine su bile decenija velikih promena u visokom obrazovanju. Pri kraju decenije su univerziteti u Japanu kamenovani od strane nasilnih studentskih pobuna koje su pogodile mnoge studentske kampuse. Neredi u kampusma su bili izazvani brojnim faktorima, uključujući pokret protiv rata u Vijetnamu, ideološke razlike između brojnih studentskih grupa u Japanu, i opštim nezadovoljstvom sistemom obrazovanja na univerzitetskom nivou.

Vlada je odgovorila na to Zakonom u kontroli univerziteta 1969. godine i početkom 1970-tih godina uvedene su dalje reforme u obrazovanju. Novi zakoni su doveli do stvaranja novih uslova za profesore i opšti nastavni program je bio revidiran. Privatne obrazovne ustanove su počele da dobijaju pomoć države i prijemni ispit za univerzitete na nivou zemlje je uveden za državne univerzitete. Za vreme ovog perioda razvilo se veliko neslaganje između vlade i grupa profesora.

Obrazovani sistem je imao centralnu ulogu da omogući da se Japan sretne sa izazovima koji su nastali kao potreba da se brzo absorbuju ideje, nauka i tehnologija sa Zapada i bio je ključni deo u oporavka Japana i brzog ekonomskog rasta u decenijama koje su sledile posle Drugog svetskog rata. 
Posle Drugog svetskog rata, usvojeni su Osnovni zakon o obrazovanju i Zakon o obrazovanjju školama 1947 pod upravom okupacionih sila. Ovaj drugi zakon je definisao sistem koji je i danas u upotrebi: šest godina osnovne škole $3+3$ godine srednje i dve ili četiri godine fakulteta. Pohađanje osnovne škole i prve tri godine je obavezno.

Uprkos brojnim promenama u obrazovanju koje su se pojavile od 1868. godine, a posebno posle 1945 . godine, obrazovni sistem i dalje reflektuje dugotrajne kulturne i filozofske ideje: da učenju u obrazovanju treba ozbiljno pristupiti i da su razvoj karaktera i morala deo obrazovanja. Meritokratsko nasleđe Meiđi perioda se nastavilo, kao i centralizovana struktura obrazovanja. Interes za adaptiranje stranih ideja i metoda u japanske tradicije i sistema se nastavlja.

Japan ima važno mesto u svetu u oblasti obrazovanja. Cena visokog nivoa se vidi u januaru i februaru koji su poznati kao "pakao ispita". Tada studenti širom Japana polažu prijemne ispite za više razrede srednje škole i fakultete, što u većoj meri određuje smer u kojem će se nastaviti njihovi životi. Upis u najbolje škole, kakav je Univerzitet u Tokiju će im doneti najbolje poslove i pristisak je ogroman. Stopa samoubistava se povećava za vreme i posle upisnog pakla i mnogi žele da se ovo promeni

Dva perioda u japanskoj istoriji su donela socijalni, ekonomski i politički razvoj usmeren pre svega na obrazovni sistem. za vreme ova dva perioda borba za polisom nacionalnog obrazovanja je se približila široj potrazi za novom političkom ideologijom. Meiđi restauracija je drastično promenila način na koji su se obrazovali mladi Japanci. Posle prvobitnog perioda ubrzane vesternizacije, tradicionalniji pogledi su se pomešali sa novim idejama i stvorili obrazovni sistem koji će trajati do Drugog svetskog rata. Uticaj američke okupacije posle Drugog svetskog rata, od 1945. do 1952. godine ima mnogo sličnosti sa početkom Meiđi perioda zato što su okupacione sile restruktuirale japansku vladu, društvo i obrazovni sistem prema modelu sa Zapada, baš kao što se to činilo za vreme Meiđi perioda. Japanici su promenili i ograničili reforme koje je uveo vrhovni komandant savezničkih sila da bi bolje zadovoljilii potrebe svog društva.

$\mathrm{U}$ oba perioda se prvobitno naglašavale vrednosti Zapada, dok se kasnije okrenulo ka japanskim vrednostima, tako da se pronašao način da proizvede najbolje obrazovane ljude na svetu

$\mathrm{Ne}$ bi bilo tačno pretpostaviti da obrazovanje nije postojalo do Meiđi restauracije. Za vreme Tokugava perioda, od 1603. do 1868. go- 
dine, od samuraja se tražilo da poseduju bar minimalno obrazovanje da bi opravdali svoju ulogu birokrata. Ovo se postiglo kroz sistem vladinih škola koje su naglašavale konfucijansku filozofiju, čitanje, pisanje i vojni trening.

lako šogunat nije ulagao u škole za obične građane, odobravao je osnovno obrazovanje koje su ovakve škole pružale. Najveći broj ovih škola je bio lociran u hramovima i omogućavao je jednostavno konfucijansko obrazovanje u kojem se naglašavalo praktično učenje kao što je kaligrafija, čitanje naglas, arimetika, rad sa računaljkom. Do Meiđi restauracije, bilo je preko 15000 ovakvih škola koje su političari iskoristili kao osnovu novog sistema.

Uprkos znatnom uspehu obrazovnog Sistema od Drugog svetskog rata, problemi su se nastavili sve do 1980-tih godina. Neke od teškoća koje su primetili posmatrači su uključile rigidnost, prekomernu uniformisanost, nedostatak izbora, neželjeni uticaj prijemnih ispita na fakultetima i najvažnije isticanje formalnih obrazovanih akreditacija. Postoji verovanje da je obrazovanje uzrok nekih socijalnih problema za neke studente. Posojala je velika zabrinutost da li će obrazovanje u Japanu odgovarati novim zahtevima koje diktiraju internacionalni promene u svetu u 21. veku.

Fleksibilnost, kreativnost, internacionalizacija, individualnost i raznovrstnost u postale ključne reči za reformu u japanskom obrazovanju 1980-tih godina, iako su ta pitanja pokrenuta desetak godina ranije. Te promene su bile toliko značajne da su ih neki poredili sa promenama koje su pojavile kada se Japan otvorio prema Zapadu u 19. veku.

Nove reforme su sproveo Nacionalni savet za reforme u Obrazovanju između 1985. i 1987. godine. Konačni ishod je internacionalizacije obrazovanja, stavljanje težišta na nove informacione tehnologije i medije i razvijanje individualnosti, učenje u toku celog života i prilagođavanje socijalnim promenama. Da bi se ostalo u toku sa novim promenama, savet je predložio je predložio razvoj sistema obrazovanja za 21. vek, organizaciju sistema učenja u toku celog života i smanjene važnosti obrazovne osnove pojedica, poboljašanje obrazovanja na nivou univerziteta, uvođenje novih elemenata u obrazovanje osnovnih i srednjih škola, poboljšanje kvaliteta nastavnog kadra, prilagođavanje internacionalizaciji, prilagođavanje informatičkom društvu i pregled administracije i sistema finansiranja obrazovanja. Ovo se odrazilo na obrazovne i društvene aspekte reforme tako što je omogućilopregled odnosa obrazovanja i društva. lako je se pokren- 
ula debata o reformi, vlada je ubrzano počela da uvodi promene. Ove promene su imale dugotrajne posledice.

Obrazovanje žena koje je često povezano sa religijskim ograničenjima je pitanje koje se pokrenulo još u Heian periodu pre hiljadu godina. Ali tek u Periodu zaraćenih država je postalo jasno da žene moraju da se obrazuju zato što moraju da brane zemlju ako su njihovi muževi umrli. U prilog tome je išlo što ni budizam ni šintoizam nisu omalovažavali žene nego su ih smatrali za jednake.

Jedna od značajnih karakteristika u sagledavanju uticaja obrazovanja na celokupni razvoj Japana je da specifičnost japanskog sagledavaja učenja. Razumevanja su naivna, kulturalna, kontroverzna, pa čak i kontradiktorna u mnogim slučajevima, ali su ona realna, utoliko što su utemeljena u praksi. U ovome postoje kako dobre, tako i loše vesti. Dobre vesti su da je moguće očekivati da se dosta razjasni o nastavi i učenju u Japanu i da se uoče određeni zajednički obrasci, čak i »filozofije», koje podcrtavaju njihovu raznolikost. Ovo je veoma kompleksna materija koju karakterišu unutarnje ironije, a činjenica da Japanski primer može izgledati egzemplaran na površini, samo znači da što dublje ulazimo u temu, češće moramo da se suočimo sa implikacijama i kulturalnim karakteristikama koje nisu ni malo laskave. Prema tome, kako Japan ima čemu da nas nauči, tako ima i na šta da nas upozori, zasnovano na svojim bogatim i dugim iskustvima

Paradoksi i kontradikcije koje se nalaze u japanskoj kulturi učenja mogu biti upozoravajući: mi pojednostavljujemo Japan do rizika neadekvatnog razumevanja. Japanske protivurečnosti reflektuju naša sopstvena ispitivanja, na primer, kultura koja ima smisla zato što je homogena u svojim osnovnim vrednostima i pretpostavkama. Kontradiktornosti naših sopstvenih uverenja postaju očigledne kada mi pokušamo da sagledamo Japanske ideje kroz njih. Ovo se obično dešava kada poželimo da naučimo od Japanaca ili direktno primenimo neka od iskustava koja nam se čine veoma dobrim u njihovom obrazovnom sistemu. Mnogo je važnije od preslikavanja određenih tehnika obučavanja, jasno sagledati, kroz ozbiljnu komparaciju, šta mi radimo i zašto; da bismo postali svesni osnovnih pretpostavki koje činimo o učenju.

Dosta učenja se ne dešava u školama. Učenje se odigrava u okviru institucija kao što je porodica, fabrika, kancelarija, ili mnogobrojne grupe 
za provođenje slobodnog vremena. Međutim, škole i učenja u školama obezbeđuje mnogobrojne modele ili paradigme nastave učenja u industrijskim društvima. Proširujući naše istraživanje na različite oblasti, možemo utvrditi osnovne, priznate modele učenja. Možemo da pitamo: da li je praksa ista? da li je razumevanje isto?, koristeći različite studije slučajeva i dovodeći ih u međusobnu vezu, možemo da složimo opis pejzaža učenja u okviru datog društva. Sadašnji sistem u svetu obojen je, takođe, poimanjem da određena društva jesu bolja u ovom "poslu učenja» nego druga. Imamo hrpe izveštaja i studija koje nam govore o potrebi poboljšanja obrazovanja kako bi se povećao naš ekonomski uspeh, društvena pravda, kreativnost pojedinaca, pa čak i demokratski proces. I ovde, sistem javnog obrazovanja dominira našom pažnjom i postavlja granice našim istraživanjima u oblasti nastave i učenja. Pridajemo ogromnu pažnju školi i učionici, ali retko, ako ikada tražimo da lociramo temu učenja unutar ukupnosti ljudskih aktivnosti. Ključni interfejs dnevne interakcije između onoga koga naslovljavamo kao »nastavnik« (uključujući »iskustva«) i one druge koje nazivamo "učenicima«, odvija se u čitavom nizu okruženja, iz dana u dan, iz godine u godinu. Gomile hiljada takvih iskustava, stvara obrasce i proizvodi izuzetno važne razlike u formaciji kako ljudskih resursa, tako i društvenih formi. Ako upoređujemo školske sisteme, kompanije ili čitave nacionalne populacije, ono što se dešava u okruženjima za učenje »licem u lice«, ostaje najteža oblast za međukulturalna istraživanja - i prema tome, uprkos njenoj kritičnoj važnosti, to ostaje oblast koja je često zapostavljena.

\section{Društveno-ekonomski razvoj Japana}

Neprekidni kontinuitet tradicionalnih, u prvom redu religiozno-etičkih vrednosti, obezbedio je sigurnost sistema i njihovo prenošenje sa generacije na generaciju. Učinak države u domenu privrede ispoljavao se kroz neprestano stvaranje klime saradnje, pružanja informacija, davanja smernica, uputstava, kroz cirkulaciju kadrova iz državnog aparata u privredu.

Objašnjenje uspeha treba tražiti u ekonomiji obima i nastojanju da proizvodnju u svakoj grani nosi nekoliko velikih kompanija. Tajna uspeha umnogome se nalazi i u vladinim preporukama, uputstvima, direktivama, 
a jedna od značajnijih poluga je i amakudari - načelo prema kome penzionosani državni službenici odlaze u privredu.

Najviši cilj japanske politike jeste stvaranje moderne konkurentske strukture, koja se temelji na prioritetima razvoja: pedesetih godina prošlog veka - ugalj, električna energija, brodovi, čelik; šezdesetih - kapitalno-intezivne grane (brodovi, mašine, automobili, elektronika), sedamdesetih znanjem intezivne grane, da bi osamdesetih naglasak ponovo bio stavljen na tradicionalne grane (brodovi, petrohemija, papir). Opšta klima poverenja i saradnje između privrede i države nije poremećena, što je i omogućilo da tokom tridesetogodišnjeg posleratnog perioda Japan ostvaruje svake godine stopu rasta od $10 \%$.

Nabolji pokazatelj tendencije jačanja domaće valute u odnosu na američki dolar u periodu od 1971-2007.godine pokazuje sledeći grafikon: ${ }^{4}$

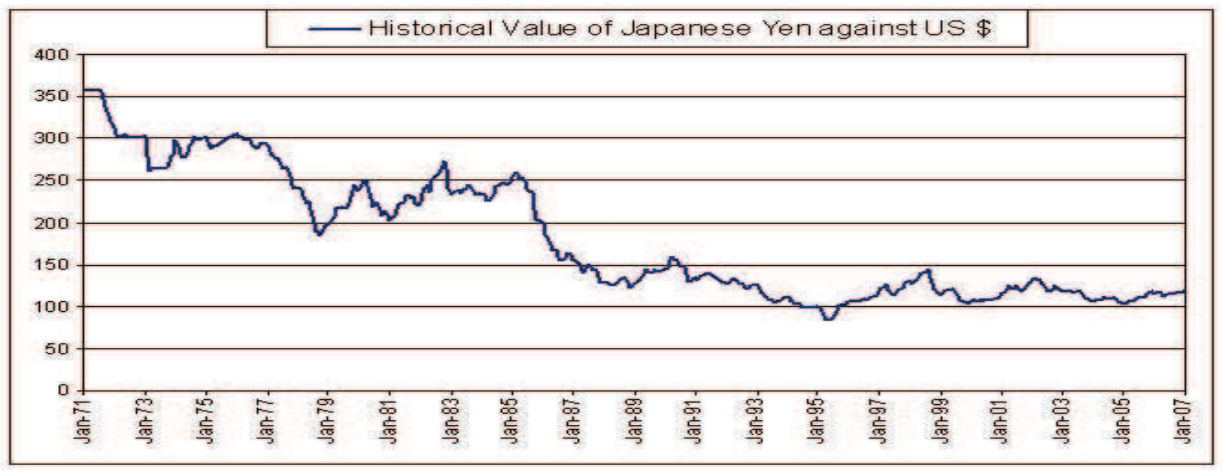

Ukoliko uporedimo Kinu i Japan u Tokugava periodu, Kina je bila civilno konfucijanska zemlja, dok je Japan bio vojno konfucijanska zemlja. U kineskom konfucijanizmu najviša vrlina je bilo čovekoljublje, dok je japanski konfucijanizam smatrao za najvažniju vrlinu odanost i žrtvovanje za svog gospodara. Kineski konfucijanizam je humanistički, dok je japanski izuzetno nacionalistički.

Imajući u vidu kulturni jaz između Kine i Japana - poznato je da je Kina u 5. i 6. veku bila na vrhuncu, u vreme kada Japan prvi put uspostavlja veze

4 http://upload.wikimedia.org/wikipedia/commons/1/12/Historical_Value_of_Yen.jpg , pristupljeno 24.5.2018. 
i kada je još uvek varavarska država - defanzivni nacionalizam je, u ime opstanka, od početka bio istaknuto obeležje japanskog konfucijanizma. Japan je u 16. veku ponovo postao svestan svog kulturnog jaza u odnosu na druge zemlje, i to u periodu kada su uspostavljeni odnosi sa zemljama Zapada.

Neposredno posle Meiđi revolucije, kojoj je ideja vodilja bila postavljanje osnove za izgradnju moderne države po uzoru na one na Zapadu, Japan je dobio priliku da stvori jedinstvenu savremenu nacionalnu državu, jer su unutrašnje komunikacije i trgovina tokom izolacije duge dva veka doprineli razvoju standardizacije jezika, usvajanja sličnih pogleda na svet, približno istih pravila ponašanja, kao i sličnih društvenih pravila i običaja koji su mogli da posluže za ujedinjenje.

Relativna lakoća sa kojom je Meiđi vlada uspela da industrijalizuje Japan delimično se može objasniti i činjenicom da bakufu raspolaže zanatskim radionicama za proizvodnju baruta, brodogradilištima i drugim fabrikama koje su krajem Tokugava perioda dosta podsećale na one na Zapadu. Da bi zaštitio japanske zanate od zapadnog izvoza i onemogućio pretvaranje Japana u čisto agrarnu zemlju, Tokugava bakufu je, sasvim nesvesno, sprovodio savršenu protekcionističku trgovinsku politiku.

Neki istoričari navode kako se ekonomska stopa rasta godišnje povećavala od $0,78 \%$ do $1,34 \%$ u periodu od 1550 . do 1700 . godine. ${ }^{5}$

Ulaskom u 18. vek Japan je počeo da pokazuje znake slabosti. Finansiranje bakufua zasnivalo se na proizvodnji pirinča. U Tokugava periodu zemlja je bila podeljena, ne po teritorijama, već po kapacitetu proizvodnje. Merna jedinica za količinu bila je koku i odnosila se na količinu pirinča koju u proseku pojede jedan čovek godišnje. Tako je, na primer, Tokugava posed brojao 6,8 miliona koku. Ipak tradicionalni neprijatelji Tokugava klana još uvek su imali kontrolu nad skoro polovinom bogatstva Japana.

Kako se privreda razvijala, povećavale su se i socijalne razlike. To je dovelo do pobuna. Druga polovina Tokugava perioda obeležena je političkim reformama koje bi trebalo da zaustave ekonomsku krizu. Prva je bila Kyoho reforma, zbog koje je Jošemine prozvan „pirinčanim šogunom“ jer je zahtevao da daimjoi daju priloge u vidu pirinča.

Na početku ovog perioda samo je mali broj bogatih farmera bio pismen, a na kraju je najveći deo bio delimično pismen. Počelo je otvaranje škole u hramovima. 
Култура и/или наука

Tokom Edo perioda (Tokugava perioda) javljaju se budističke sekte kao što su Đodo, Đodo šin, Zen i Nićiren. U prvim godinama 19. veka kultura koja je počela da se razvija u 17. veku, dostigla je svoj vrhunac. Književnost i kultura su se razvijali i u gradovima, ali i u unutrašnjosti.

$U$ isto vreme kada se bakufu suočavao sa raznim pobunama, evropske sile počele su da vrše pritisak na Japan. Visoki zastupnik Mizuno Tadakuni uspostavio je Tempo reformu, koja je dobila ime po Tempo eri (18301844). Kada je Abe Masahiro 1845. godine zamenio Tadakunija javile su se različite reakcije protiv Tempo reforme. Najveći problem predstavljao je odnos sa strancima, s obzirom da je dolazak Evropljana i Amerikanaca pedesetih godina 19. veka izazvao tenzije u zemlji.

Jačanje vlasništva nad zemljom od strane poljoprivrednika bilo je praćeno istovremenim slabljenjem moći feudalnog gospodara, a tako je slabila i osnovica feudalne organizacije. Siromašni ratnici nisu više mogli da žive kako je to priličilo pripadnicima vladajuće klase i morali su da se bave drugim poslovima kako bi preživeli.

Pokretačka snaga Meiđi restauracije bila je inteligencija, čije su jezgro činili ratnici niskog roda i uparvo je ta inteligencija doprinela prekidu perioda izolacije. Javilo se pitanje da li prognati varvare (mislilo se na Zapad) ili odobriti politiku otvaranja zemlje. Pozivanje na osećanje pojedinca unosilo je neizvesnost, jer su se ljudi emotivno zalagali za proterivanje, ali su u praksi odobravali politiku otvaranja. U takvoj situaciji Naosuke, pristalica politike otvaranja, postaje premijer bakufua. On je bez prethodnog carevog odobrenja, zaključio trgovinske ugovore, a feudalne gospodare koji su se protivili stavio u kućni pritvor. Zato je i ubijen, pa su klanovi Ćošu i Sacuma predložili teoriju ujedinjenja dvora i bakufua. Godine 1863. car je odobrio edikt o proterivanju svih stranaca.

Pripadnici Sacuma i Aizu klana organizovali su državni udar protiv plemstva koje se protivilo strancima. Kako su pripadnici Sacuma klana bili anti-bakufu raspoloženi, ojačali su svoje savezništvo sa Ćošu klanom. U centru pažnje sada je dilema - treba li očuvati Tokugava bakufu strukturu ili izgraditi potpuno novu, modernu i jedinstvenu nacionalnu državu. Po planu o jedinstvu dvora i bakufua, car bi zadržao svoje centralno mesto u političkom sistemu zemlje, a Tokugava sistem bi se zadržao, mada donekle izmenjen. Intelektualci su ovo rešenje smatrali pogrešnim, pa su pokušali da osujete ovo ujedinjenje, ali ih je car kaznio. Mesec dana kasnije car umire i nasleđuje ga šesnaestogodišnji sin Meiđi. lako je vlast 
šogunata sve manja, vraćena caru krajem 1867. godine, rat između bakufua i udruženih snaga Sacuma-Ćošu je nastavljen. U Meiđi revoluciji pobedu su odneli klanovi Sacuma i Ćošu, koji su koristili lako oružje sa Zapada. Novu vladu su formirali oni koji su se zalagali za proterivanje varvara, mada su postepeno shvatili svoju pogrešku i uvideli da će odbrambena politika biti ona koja će modernizovati Japan.

Godine 1871. ukida se pravo dominacije feudalnih gospodara i poseda klanova, a 1873. donet je edikt o regrutovanju, kojim ratnici nisu više bili u obavezi da jedini brane zemlju. Odmah posle revolucije nova vlada je ministra za religiozna pitanja stavila iznad premijera i proklamovala šintoizam kao nacionalnu religiju.

Prisutna su i tumačenja onih koji smatraju da je revoluciju uzrokovala ogromna erupcija ekonomskih problema koji su se gomilali za vreme Tokugava sistema. U prilog tome navode se mnogi seljački ustanci, ali svest seljaka u to vreme nije ni izbliza bila u toj meri razvijena da bi oni sproveli rušenje feudalne strukture i uspostavili sistem jedinstvene vladavine. Meiđi revolucija se nije pretvorila u veliki građanski rat upravo zato što se klanovi, osim klanova Sacuma i Ćošu, nisu mahom interesovali za revoluciju. Nova vlada je ukinula mnoga ograničenja klasnog sistema, organizovala sistem obrazovanja i modernizovala državnu strukturu.

Japanska kapitalistička klasa bila je malobrojna i slaba, pa je Meiđi vlada bila primorana da gradi moderne fabrike, bilo novcem od poreza prikupljanog od seljaštva ili kapitalom dobijenim emisijom papirnog novca. Dolazi do inflacije, a bankrotstva su bila masovna pojava. Vlada je bila prisiljena da svoje fabrike jeftino proda, a oni koji su ih kupili preko noći postaju kapitalisti i tako je stvoren jedan od preduslova za razvoj kapitalizma u Japanu. Da kojim slučajem Japanci nisu prihvatili veru u štedljivost (konfucijansko učenje) izvesno je da moderni kapitalizam ne bi mogao da se razvije u Japanu.

Nacionalističko-kapitalistička privreda zasniva se na sistemu starešinstva i doživotnom zapošljavanju. Od samog početka, Meiđi vlada je bila usavršena birokratska forma ovog sistema. Zato i nije iznenađujuće to što se japanski kapitalizam od samog početka razvijao kao državni kapitalizam, kao privreda koju su usmeravali i kojom rukovode birokrate.

Japanski kapitalizam razvio se iz nukleusa sačinjenog od fabrika kojima se upravljalo na osnovu konfucijanske ideologije. Japanci su veličali red i zakon, a liberalizam i individualizam su smatrali preprekama na putu ostvarenja reda i zakona. Zemlja se posle Meiđi revolucije otvorila, ali to 
se u najvećoj meri odnosilo na trgovinu, pa japanska vlada još uvek nije bila spremna da zemlju otvori za strani kapital, zato je ona svojim snagama morala da stvara kapital za razvoj.

$U$ to vreme vrlo su retki radnici sa kvalifikacijama i razvijenom industrijskom kulturom. Vlada je morala da obezbedi ponudu sve većeg broja tih kvalifikovanih i odgovornih radnika. Zato je od samog početka veliki pažnju posvetila obrazovanom sistemu. Donošenjem Gakusei (Zakona o obrazovanju) 1872. vlada je otpočela izgradnju modernog školskog sistema: teritorija cele zemlje podeljena je na 50000 okruga sa po 600 stanovnika, a u svakom okrugu je postojala osnovna škola i obrazovanje je bilo obavezno bez obzira na stepen, status i pol.

Sve do sredine Meiđi perioda privatna preduzeća su na tradicionalana način regrutovala radnu snagu. Preduzeće je zaključivalo ugovor sa gazdom i plaćalo mu fiksnu sumu, a gazda je regrutovao radnike iz siromašnih seoskih porodica, koji su svakako bili nekvalifikovani. Zato su neretko krajem 19 i početkom 20. veka kompanije krale radnu snagu jedna od druge, pa se naročita pažnja poklanjala duhu odanosti, kako bi se na duži rok obezbedila stalna radna snaga. Kao stimulacija uvedene su nadnice u zavisnosti od dužine radnog staža. Kupujući odanost radnika kroz ove nadnice, sektor velikih preduzeća zauzvrat je tražio doživotno zapošljavanje. Ukoliko bi neko bez potpune saglasnosti poslodavca napustio preduzeće smatran je izdajnikom, a druga preduzeća su oklevala da ove izdajnike zapošljavaju. Zato su ovi izdajnici morali da potraže zaposlenje u srednjim i malim preduzećima. Mogućnosti zapošljavanja u malim i srednjim preduzećima su bile stoga znatne, dok se prilika za zapošljavanje u nekom od velikih preduzeća, koja su se takmičila sa preduzećima razvijenih zemalja Zapada, pružala samo jednom u životu posle završetka škole ili fakulteta.

Sistem u kome su radnici doživotno radili i u kome je kompanija odlučivala o njihovom angažovanju podsticao je doživotno vezivanje radnika za preduzeće. Radnici su tokom radnog veka radili razne poslove o čemu nisu sami odlučivali, pa nisu imali izraženu svest o radnim zadacima i poslu koji treba obavljati. To je samo pojačavalo lojalnost kompaniji. Nameštenici su menjali poslove prema planu obrazovanja i obuke preduzeća, a raspodela radnih zadataka vršena je unutar kompanije koja je sama snosila sve troškove u vezi organizacije jednog ovakvog sistema. Neka velika preduzeća osnivala su i svoje škole u kojima se isključivo školovala i obučavala njihova radna snaga. U malim i srednjim preduzećima 
nije bilo organizovanog školovanja radnika, već su oni učili na poslu od starijih radnika.

U konfucijanskom kapitalističkom društvu odana služba je najveća vrlina i u etičkom i materijalističkom smislu reči. Tokom Tokugava perioda postojale su četiri klase: ratnici, seljaci, trgovci i zanatlije. Odano služenje se zahtevalo samo od ratnika koji su uživali potpuni status i nisu mogli da rade za svoje zadovoljstvo. Ostale tri klase su bile nisko na lestvici, ali im je zauzvrat omogućeno da rade i zarađuju. Nešto slično važi i za preduzeća. Od izuzetnih radnika u velikim preduzećima očekuje se potpuna odanost preduzeću, dok su radnici u manjim preduzećima manje plaćeni, ali mogu da uživaju u ličnoj slobodi.

$U$ vreme Meiđi revolucije presudan je bio ishod ispita za prijem $u$ preduzeće koji su bili jedinstvena šansa. Posle Meiđi perioda, Japan je postao društvo u kome je postojala velika konkurencija između pojedinca. U Japanu nameštenici formiraju tim koji kao jedna celina konkuriše timovima drugih kompanija.

Uloga koju su velike kompanije imale u pretvaranju Japana u snažnu zemlju sposobnu da se suprotstavi Zapadu, značila je da su ta preduzeća svesna nacionalnih ciljeva i da imaju u vidu interese države; ona su u svakom trenutku bila spremna da pruže podršku vladi. Polazeći od takvih shvatanja, nekih 50-tak godina posle Meiđi revolucije, Japan je kao jedinstvena zemlja izgradio modernu državu.

Onaj ko želi da shvati, ili bar pokuša da shvati japansko društvo, političko-ekonomsku situaciju danas, trebalo bi da preispita merila koja se zasnivaju na zapadnjačkom poimanju države, politike, društva i privrede, uvažavajući društvene i kulturne osobenosti Japana. Japan je svakako preuzeo institucije i ideje prilikom razvoja privrede i ekonomije, ali im je istovremeno dao vlastiti oblik i nove sadržaje. Modernizacija Azije, koju je kasno zahvatila industrijska revolucija, pretežno se odigrala u 20. veku. Za vreme tog procesa koji je u Japanu započeo već poslednjih decenija 19. veka, mahovi privredne i društvene modernizacije ni u kom se slučaju nisu odvijale paralelno. Društvena modernizacija je mnogo duže ostala usko vezana za tradicionalne obrasce. Napredno zapadno mišljenje zahvatilo je prvenstveno privredu, delimično politiku, a u najmanjoj meri društvo.

Modernizacija Japana - primer drugim azijskim zemljama - bila je olakšana time što je ta dalekoistočna ostrvska zemlja bila u stanju da sačuva svoj identitet, da sledi zatvorenu razvojnu strategiju i pri tom je mogla da se osloni na homogeno stanovništvo koje je istovremeno bilo 
spremno da uči. Japansko društvo je, osim toga, bilo „korporativno“ društvo sa visokim stepenom vertikalne integracije. Odnosi unutar porodice, kao i između porodice i državne zajednice, bili su ustrojeni strogo hijerarhijski - oni su bili uzor koji je poslužio u procesu privredne integracije.

Sa stanovišta teorije svetske privrede, Japan je iz dva razloga izbegao lošu sudbinu. Prvi razlog je taj što su kolonijalna osvajanja prvenstveno bila usmerena ka Kini i Indiji, a ne ka Japanu. Drugi razlog je taj što su, kada je Japan došao u središte interesovanja, izbili oštri sukobi među kolonijalnim metropolama što je Japanu omogućilo da se političkoekonomskim sredstvima, a ne isključivo kroz vojno pokoravanje, uključi u svetsku razmenu.

Impresivni rezultat u privredi - savremena struktura privrede, dinamički razvoj, dominacija u oblasti elektronike, robotike, automobilistike i hemijske industrije, ostvareni u oskudici prirodnih resursa i energetskih izvora, objašnjava se vrlo različitim faktorima. Tako se ističe značaj psihološko-motivacionih faktora kod pojedinaca, tradicionalna socioklasna struktura društva, i uticaj konfuciajnskog kapitalističkog duha. Ne sporeći značaj materijalnih faktora, može se istaći uticaj religiozne svesti i nacionalnog etnosa Japana.

Bitna razlika Zapada i Istoka vezana je za činjenicu da puritanski protestantski racionalizam nastoji da ostvari kontrolu nad svetom, dok konfucijanski racionalizam upućuje na prilagođavanje svetu na racionalan način. Najvažnija vrlina u Japanu je pokornost i lojalnost, dok je u Kini i Koreji čovekoljublje. U Kini biti lojalan znači biti lojalan prema svojoj savesti, a u Japanu to podrazumeva bespogovorno pokoravanje državi i gospodaru. Kineski konfucijanisti su odbijali svaki kontakt sa Zapadom, a Japanci su bili spremni, mada posle dugotrajnih borbi, da njegova znanja usvajaju i zemlju otvaraju prema svetu. Ima ironije u tome da su se oni koji su se više protivili otvaranju, Kinezi, pre i naslino uključili u svetsku privredu, dok su drugi, Japanci, kasnije i političko-ekonomskim sredstvima uspostavili veze sa svetom.

Učinivši preuzete religije ideologijama koje su snažno podržale postojeći režim, posle Meiđi revolucije, Japan je lako i brzo došao u situaciju da može da koristi zapadnu tehnologiju za razvoj države. Svaki pojedinac bio je duboko prožet nacionalističkim osećanjima, pa je snaga javnog mnjenja mogla da dovede do potiskivanja bilo kakve liberalističke ekonomske aktivnosti. 


\section{Culture and/or Science}

U Japanu modernizacija nije zahvatala sve oblasti zemlje na isti način i istim tempom. U svakoj oblasti je stvoreno jezgro koje je prednjačilo i bilo izjednačeno sa Zapadom, pa je modernizacija napredovala kroz podsticanje tih ključnih sektora.

Zbog važeće ideologije japanska privreda se jako puno razlikuje od slobodnog preduzetničkog sistema na Zapadu.

Nijedna zemlja ne može napredovati ako zanemari sopstvenu prošlost, koja ograničava njen sadašnji razvoj.

Svaka naučna misao koja zanemari istoriju, iako na prvi pogled verno odražava stvarnost, vremenom postaje vrlo opasna. I ekonomska politika kojoj nedostaje istorijska perspektiva podjednako je opasna.

Politika koja se pokazala uspešnom u Japanu može biti štetna u Britaniji i obratno, jer postoje velike razlike u etnosu, u ponašanju ljudi i drugim kulturnim obeležjima koja su nasleđena iz prošlosti.

\section{Zašto je Japan uspeo?}

Dok antropolog Nakane ${ }^{6}$ pokušava u eseju "o vertikalnom društvu" da pokaže kako se japansko preduzeće proizvodi iz hijerarhijskog modela japanske porodice, nastale iz feudalnog društva; ekonomista Morišima7 prikazuje veberijanske modele i pokušava da dokaže kako konfucijanizam ima u Japanu onu ulogu koju je na Zapadu imao protestantizam u razvoju kapitalizma. Ove studije fasciniraju, jer zauzimaju teren na kome se Zapadnjaci ne osećaju ni malo prijatno, a to je polje japanske kulture.

Ipak, po strani od ideološke prirode tumačenja, neki autori (bilo zapadni, bilo japanski) uvode elemente analize, da bi shvatili načine "tajne japanske sposobnosti da se ubace na strana tržišta" (ovo se objašnjava sistematskom hajkom na ekonomske i finansijske informacije trgovačkih društava novog tipa; neki su rešenje videli u ministarstvu trgovine i industrije, vrsti super-tehnostrukture snabdevene iznenađujućom sposobnošću za „predusretanjem“, ministarstvu koje je dobro poznavalo vrednosti investiranja i stope porasta tih godina).

Međutim, tek oko 1980.god. se došlo na ideju da japanska produk- 
tivnost daje takve rezultate zahvaljujući organizaciji rada zasnovanoj na efikasnijim principima. I na kraju, 1990. god. Japan, dotle rezervisan samo za specijalizovane posmatrače, postaje tema razmišljanja raznih istraživača ekonomista, sociologa, istoričara preduzeća, bilo sa Zapada bilo iz samog Japana. Žarište istraživanja se pomera na fabrički teren.

Uspeh japanskih firmi se od 1990. god. objašnjava na primeru preduzeća Tojota; navodi se da je skup inovacija uvedenih u fabrike za Japan važan koliko je za SAD bio važan fordizam.

Japanski uspon se objašnjava prednošću revolucionarne organizacije rada. Ova organizacija je, po mnogim mišljenjima, suprotna američkom načelu organizacije.

Japanska fabrika nastoji da dospecijalizuje profesionalne radnike, transformišući ih ne kao kod Forda u parcijalne radnike, nego u pluroperatore, u polivalentne profesionalce. Japansko preduzeće ne traži samo brzinu operacije individualnog radnika, nego i efikasnost celokupnog sistema. Procesi organizacije rada na kojima su japanski inženjeri sistematski radili su u suštini antifordovski, po integraciji kontrole kvaliteta operacija proizvodnje, po ponovnom uvođenju zadataka popravke, kao i po primenljivosti poslova. Japanska fabrika, ruši tejlorijanske principe: raditi tako da radnik ne bude prikovan za svoje mesto. Fleksibilnost je u osnovi produktivnosti. Prepoznavanje umešnosti radnika utiče na njegovu bolju integraciju u preduzeću. Radnik je čvrst deo organizacije rada, podstiče se njegova inteligencija, slušaju se njegove sugestije, što ga čini efikasnijim proizvođačem.

Posebno zanimljiv je fenomen štednje u Japanu. Naime, Japanci tradicionalno vole da štede novac u bankama. $U$ posleratnom periodu ta njihova navika je bila pospešena visokim kamatama koje su omogućile veći obrt kapitala i veća ulaganja u industriju i ostale privredne grane. Procene ekonomista su da ukupna štednja Japanaca danas iznosi oko 13 hiljada milijardi dolara, odnosno koliko i ukupna ušteda građana Nemačke, Velike Britanije, Francuske i SAD zajedno. O kolikoj sumi je zapravo reč možda najbolje govori podatak da je svojevremeno za desetogodišnju eksploataciju resursa Sibira nuđeno tri hiljade milijardi dolara.

Danas, međutim, japanske banke obračunavaju godišnju kamatu na štednju ispod jedan odsto, pa se mnogi Japanci sve više opredeljuju da svoje uloge povere bankama $u$ inostranstvu. Na taj način je iz Japana za poslednje tri godine otišlo 350 milijardi dolara. 


\section{Culture and/or Science}

Naime, japanska kompanija jača svoj položaj razvijajući osećaj odanosti pojedinaca prema kompaniji i omogućava im odgovarajuće školovanje i osposobljavanje. Kompanija daje prioritet harmoniji zaposlenih i njihovom posvećibvanju svom preduzeću, a ne njihovoj međusobnoj konkurenciji.

Japansko društvo jeste društvo oštre konkurencije, mada se konkurencija ne odvija među pojedincima: pojedinac i po cenu života mora učestvovati u bitci grupne konkurencije. Ta strategija omogućila je Japanu da do 1975. godine u mnogim oblastima dostigne zemlje Zapada, a u nekima i da ih prestigne.

Japan je stalno bio u položaju da mora da prevazilazi kulturni jaz koji je postojao u odnosu na druge zemlje. Ova vrsta slabosti učinila je japansku vladajuću klasu ofanzivnom i defanzivnom, a sve što je preuzeto iz drugih zemalja menjano je u tom smislu da potpomogne razvoj ili odbranu Japana.

\section{Osnovne karakteristike japanskog puta u modernizaciju i brz ekonomski rast}

Kao četiri glavna stuba uspašne modernizacije Japana se navode meritokratija, obrazovanje, saradnja privatnog i državnog sektora i uvoz i usvajanje tuđih znanja, ali u suštini sva četiri se svode na ogromno znanje i na finansijsku potporu, tako da je po mom mišljenju neizvodljivo i u neku ruku nepravedno izdvojeno pisati o svakom od ovih elemanata pojedinačno jer su svi zajedno tesno povezani, isprepletani i utiču međusobno jedan na drugi.

U vreme Meiđi perioda (1868. - 1912.) Japan je započeo svoju modernizaciju. Restauracijom od godine 1868. okončan je 265-ogodišnji feudalni Tokugawa šogunat. Pre početka Meiđi reformi, domaća ekonomija je bila razorena. U prvim diplomatskim ugovorima sa Sjedinjenim Američkim Državama dogovoreno je naseljavanje stranaca u Japan kome, kao i nekim drugim reformama u društvu, samurajski sloj pruža otpor.

Prva reforma je proglašenje Petočlane zakletve 1868.koja se ticala ciljeva Meiđi vladara čiji bi zadatak bio da podignu moral i pridobiju finansijsku podršku za novu vladu. Tih pet odredbi su bile: uspostavljanje savetodavnih skupština, uključenje svih klasa obavljanju državnih poslo- 
va, opoziv raskošnih zakona i klasnih ograničenja pri zapošljavanju, zamena loših običaja prikladnim zakonima prirode, i što je najvažnije:međunarodna potraga za znanjem kako bi se ojačali temelji carske vladavine. Kroz razne poslovne ugovore sa zemljama Zapada, Japan je u neku ruku lišen suvereniteta i prava da kontroliše svoju trgovinu. Revizija ovih ugovora je u Meiđi periodu bio prioritet vlade.

Međutim, kao dva najvažnija razloga munjevite uspešne modernizacije Japana se navodi zapošljavanje oko 3000 stranih eksperata koji su nazivani o-yatoi ili gai-koku-jin. Strani stručnjaci su rado dolazili u Japan, jer pored upoznavanja sa potpuno novom kulturom, vlada im je garantovala visoku platu i veliki ugled. Oni su bili specijalizovani za razna polja,između ostalog za engleski jezik, nauke, inženjering, vojsku, mornaricu... i školovanje mnogih Japanaca u prekomorskim zemljama - što se odnosi na petu odredbu iz 1868.godine - potražnja za znanjem se odvija širom celog sveta da bi se osnažili temelji carske vladavine. Nakon završetka ugovora stranih stručnjaka, kada bi japanski studenti stekli neophodna znanja, strani stručnjaci su zamenjivani domaćim. Ovaj proces modernizacije je bio pažljivo nadgledan od strane Meiđi vlade.

Dakle, Japan je koristio zapadnjačke tehnologije (legalno, uvozom patenta i licenci), usavršavao ih, usavršavao biznis model (npr. izmislili su JIT (just-in-time) sistem rada sa zalihama), podigli efikasnost privrede i postali model za tzv. male tigrove po Aziji kao sto je npr. Severna Koreja. Na taj način su postali izuzetno konkurentni sa zapadnim ekonomijama.

Pomenuti JIT (Just in Time) nije tehnologija nego označava filozofiju. Odnosi se na proizvodnju koja izlazi zadovoljava zahteve mušterije i po pitanju kvaliteta i kvantiteta i to tacno na vreme. U poslednje vreme oznacava proizvodnju uz minimalne gubitke(vremena i materijala).

U Meiđi periodu su dominantne reforme u obrazovanju. Po okončanju dvestogodišnje izolacije, Japan je primer koji nam daje do znanja da je moguće sprovesti reforme u ekonomskom, političkom i socijalnom sistemu jedne zemlje po modelu država koje su u neku ruku po pitanju kulture totalne suprotnosti sa tom zemljom. Na prvom mestu su znanja usvojena iz oblasti tehničkih nauka i metoda poslovnog upravljanja.

Obrazovne institucije perioda koji je prethodio (Tokugawa perioda) su već bile toliko razvijene da su mogle da posluže kao preteče osnovnim školama. Sedamdesetih godina 19.veka se uvode osnovne škole u obrazovni sistem Japana i predstavljaju polaznu osnovu procesa modernizacije u 
Japanu, jer, reforma obrazovnog sistema je uvek lakša ako su građani obrazovani i dobro informisani. Na primer feudalni gospodari su obrazovali zaseban obrazovni sistem za svoje podanike. Samuraji su se edukovali u lokalnim školama ili privatnim akademijama i izučavali su kaligrafiju, aritmetiku, pisanje i čitanje poezije, zapadnu medicinu, zapadne vojne nauke, tj.kombinaciju tradicionalnog japanskog i evropskih nauka. Ne samo da je posle ukidanja cenzure stranih udžbenika omogućeno Japancima da se usavršavaju u medicini, hirurgiji,navigaciji, geografiji, hemiji, već su i stranci sa Zapada imali priliku da se uvere u visoku umetničku vrednost japanskog stvaralaštva: značajna je proizvodnja keramike, slikarstvo i moda.

Kod Toba Fushimi je 1868. godine održana bitka u kojoj su poražene samurajske i antireformističke snage. Prilikom reformi je bilo važno da se stvari sa Zapada primenjuju selektivno, a da se pri tom očuvaju običaji i osnovna obeležja tradicionalne kulture. Ovakva politika vlade je sažeta u slogan Wakon Yousai(zapadne nauke, japanski duh). Ozlojeđenost je bila prisutna u smislu da su zapadnjački običaji i način odevanja postajali popularni i to je pretilo uništenju tradicionalne kulture. Simpatično je pomenuti da je čak 1873. u Japanu formiran prvi bejzbol tim. A što se tiče prihvatanja istočnih običaja na zapadu, na primer, strance je šokiralo javno kupanje i tetoviranje.

Nije sve ni tako zlatno u Meiđi periodu. Yakuze cvetaju, razvijaju poslove vezane za šverc, ucene, iznude, reketiranje i organizovanje prostitucije ...

Pol je uvek bio jedan od glavnih principa raslojavanja u Japanu. Razlika polova u kulturnom smislu je varirala u različitim periodima i u okviru različitih društvenih klasa. Na primer, u 12.veku, u Heian periodu, žena je mogla naslediti imovinu i voditi je sama. Kasnije, u vreme šogunata, status žene je opao.

Na početku industrijalizacije, žene su radile u fabrikama izrabljujućim u nezdravim uslovima bez ikakve lične autonomije. U Meiđi periodu, industrijalzacija i urbanizacija je umanjila autoritet očeva i muževa, a u isto vreme lišila žene njihovih prava i prepustila ih volji glave domaćinstva.

Status žene u društvu je ujedno i mera napretka jednog društva. Vlada je smatrala da je poboljšanje statusa žene ključno za pridobijanje poštovanja Zapada, ali sa druge strane, nisu bili radi da menjaju tradicionalnu ženu, pa se većina drugih reformi odigravala na zadovoljavajućem nivou, a što manje se činilo na promeni statusa japanske žene. Pored takvih tendencija vlade, budizam i šintoizam nisu potcenjivali žene već ih smatrali ravnopravnim sa muškarcima. 
Glavna promena se ticala obrazovanja žena. U Sengoku periodu je razvijena svest o važnosti obrazovanja žena,jer su one te koje ostaju da brane zemlju kada njihovi muževi poginu u ratu. 1871.su poslate u inostranstvo. Iwakura misija (posećena je između ostalog Svetska izložba u Beču koja bitno utiče na formiranje slike o Zapadu i njegovim dostignućima) je uključila 45 studenata, od kojih 5 devojčica koje su bile prve Japanke koje su izučavale školu u inostranstvu. Značajno je pomenuti da je Tsuda Umeko bila najmlađa, imala je samo 7 godina. Mnogo godina kasnije, po povratku u Japan je osnovala Englesku školu za žene, koja je kasnije nazvana Tsuda koledž.

Neke druge reforme koje su bile vezane za žene su se odnosile na prostitutke i konkubine... Što se tiče Zapadne mode, na primer, muškarci su mogli da skrate kosu, ali ne i žene.

Još jedan od faktora koji je doprineo dinamičnom razvoju Japana je bio kulturološke prirode: Konfučijanizam. Tradicije Konfučijanizma su obezbedile Japanu model za biranje kompetetnih vođa, zatim, stavlja se akcenat na vrednosti grupe,tima, a ne samo pojedinca. Ovo je potpomoglo industrijalizaciju tako što je populacija ubeđena da prihvati duge sate napornog rada uz relativno niske nadoknade a da ne proispituje politiku vlade. Konfučijanizam uči svoje pristalice da ne sumnjaju u autoritete, sebi nadređene. Ovakva tradicija se prenela i u posleratni period kada su se formirali autoritarni režimi... Manjak, gotovo i ne postojanje neslaganja omogućuje opstanak stabilne vlade.

Pošto Konfučijanizam daje prednost grupi, a ne pojedincu, tako je vlada trošila manje na programe socijalne pomoći, a kanalisala više sredstava u infrastrukturu i industriju.

Glavni saobraćaj je bio vodeni. Kopneni saobraćaj je bio primitivan. Robu su prenosili ljudi ili konji, nisu postojale kočije. Velike reke su bile prepreke za kopneni saobraćaj jer nije bilo mostova. Što se tiče političke pozadine, nije bilo u interesu države da im stranci izgrade prugu jer bi to značilo da ti stranci imaju neka prava na prugu u Japanu. Harry Parkes, britanski ministar u Japanu je bio pobornik teorije po kojoj bi izgradnja železnice modernizovala Japan i insistirao je na tome da vlada Japana uloži u železnicu. 1869.godina je bila još jedna od siromašnih po pitanju žetve pirinča u Tohoku-u i železnicom bi se pirinač iz nekih drugih oblasti brzo prevozio to Tohoku-a i tako bi se smanjila glad. Meiđi vlada je prihvatila izgradnju železnice iz političkih razloga - kako bi se ukinuo feudalni pore- 
dak i centralizovala moć u Japanu. Odlučeno je da se prva pruga sagradi između Tokija i Yokohame, koja je tada bila jedna od retkih luka otvorenih za međunarodnu trgovinu. Za izgradnju železnice je unajmljeno oko 300 uglavnom britanskih stručnjaka koji su ujedno i podučavali japanske radnike. Kao glavni inženjer se pominje Edmund Morel čiji se doprinos ogledao u važnim predlozima japanskoj vladi koji su se ticali inženjerske administracije i obrazovanja. Umro je od tuberkuloze, godinu dana pre nego što je japanska železnica ugledala svetlost dana.

Masaru Inoue je bio veoma značajna osoba u istoriji japanske železnicu. Pošto je za vreme Tokugawa šogunata bilo zabranjeno putovati u inostranstvo, Inoue je tajno napustio zemlju,otišao u Englesku i pohađao koledž gde se specijalizovao za prvog japanskog poznavaoca železnice.

Sve te promene su propratili problemi kod kuće i opasnosti spolja ili kako su to Japanci nazvali naiyu gaikan ... domaće i strane krize. Seljacima su povećane takse na zamljište.

Japan je modernizovao i vojsku, pa samuraji više nisu bili potrebni. Stipendije za samuraje obustavljene Veliki je trošak na borbu protiv pobunjenih samuraja sa juga. Zemlja je u dugovima. Potrebno je "prodati" operaciju izgradnje pruge. Vlada "prodaje" taj projekat imućnim porodicama koje su kasnije prerasle u ogromne korporacije (Mitsui, Mitsubishi(tri dijamanta), Sumitomo i Yasuda). To praktično predstavlja saradnju državnog i privatnog sektora. Vladi su bili neophodni zaibatsu-i koliko i zaibatsu-ima vlada. Vlada i velike korporacije su te koje su vodile naciju, pozajmljujući tehnologiju Zapada i tako je Japan dospeo na vrh Azijskog tržišta - uvozeći sirovine i izvozeći gotove proizvode,uglavnom tekstilne.

Jedna od najznačajnijih figura u razvoju Japana je bio Shibusawa Eiichi. U mladosti se bavio porodičnim biznisom, proizvodnjom i prodajom indiga i uzgajanjem svilenih buba. Kasnije je bio u službi Hitotsubashi Yoshinobu(koji je postao poslednji Tokugawa šogun). Bitan je momenat u njegovom životu kada sa izvesnom japanskom delegacijom posećuje Francusku i druge evropske države. Tada, kada je prvi put bio u kontaktu sa Evropom, shvatio važnost industrijskog i ekonomskog razvoja.

Po povratku u Japan, pozvan je od strane vlade na mesto ministra finansija. 1873.se povukao sa te pozicije, ali je zato postao upravnik prve moderne japanske banke is a tom funkcijom je uticao na razvitak mnogih poslova u Japanu koji su doprineli modernizaciji. Između ostalog je vodio mnoge projekte za poboljšanje školstva, pogotovu je podržavao obrazovanje žena. 
I tako, na samom kraju, Japanci su razvili društveno uređenje verno svojoj tradijici, a opet otvoreno prema svetu.

Obrazovanje u Japanu je preuzelo funkciju multiplikatora: vrednosti koje su bile u posedu malog broja ljudi su se proširile na celu naciju. Od malog broja obrazovanih ljudi, Japan je danas zemlja se najvećom stopom pismenosti. A obrazovanje koje se temelji na kofučijanskim principima je omogućilo da se zemlja brzo uključi u svetske tokove i postane jedna od sila koje diktiraju razvoj. Konfucijanska etika je taj najvažniji faktor koji će omogućiti da plod rada pojedica pre svega pripada državi. Ipak, moralo je da dođe do promene u tradicionalnom shvatanju konfucijanstva kada je klasa na najvišem stupnju hijerarhijske lesvice- samuraji postala zavisna od sloja koji je bio na najnižoj lestvici - trgovaca, što je dovelo do promene u sistemu u kojem ne dolazi do mešanja klasa i trgovina više nije smatrana „prljavim poslom“.

\section{Literatura}

Craig, Albert M. 1968. Fukuzawa Yukichi: The Philosophical Foundations of Meiji Nationalism. In Political Development in modern Japan, ed. Robert E. Ward, pp. 120-1. Princeton, N.J.: Princeton University Press

Ćetković, Emilija. 2009. Školski sistem u Japanu, 2009, Beograd.

De Bary, William Theodore, Carol Gluck, Arthur E. Tiedemann. 2005. Sources of Japanese Tradition, Vol. 2. New York: Columbia University Press

Duus, Peter. 1988. The Cambridge history of Japan, The Twentieth Century, Volume 6. Cambridge: Cambridge University Press.

Jansen, Marius. 1989. The Cambridge history of Japan, The Nineteenth Century, Volume 5. Cambridge: Cambridge Uversity Press.

Jansen, Marius B. 2002. The making of modern Japan, Harvard: Harvard University Press. Johnson, Chalmers 1982. MITI and the Japanese Miracle. Stanford, California: Stanford University Press

Kevenherster, Paul 1993. Politika i društvo u Japanu, Mannheim: B.I.Tachenbuchverlag Marwala, Tshilidzi 2009. Foundations for a Developmental State: A case for technical education Morishima, Michio 1982. Why Has Japan 'Succeeded'?, Cambridge: Cambridge University Press Morišima, Mićio. 1986. Zašto je Japan uspeo?. Beograd: Izdavačka radna organizacija Rad.

Nakane, Chie 1970. Japanese society, Berkeley and Los Angeles, California: University of California Press.

Pyle, Kenneth B. 1996. The Making of Modern Japan, Lexington: D.C. Heath

Sagers, Johnn H 2006. Origins of Japanese Wealth and Power, New York: Palgrave Macmillan 
わが文壇的自叙伝 (My Literary World Basis Autobiography), Genji Keita, Shueisha, Tokyo 1975, ASIN: B000J98YUU

子どもが幸せになる学習塾 (Children to Be Happy with The Cram School), Tadashi Naruse, PHP Research Institute, Kyoto 2011, ISBN-13: 978-4569795669

子どもの “自学”する力を育むKUMON (KUMON fosters the power to “self-study" of the child), Mikiko Taga, PHP Research Institute, Kyoto 2014, ISBN-13: 9784569818771

子供は東大へ入れる!! 一新教育ママの受験作戦-(Put My Children to the University of Tokyo !! - New Education mom exam strategy-) Chieko Watanabe data House, Tokyo 2004, ISBN-13: 978-4887187719

私の人生案内 (My life guide), Genji Keita, Chukobunko, Tokyo 2004, ISBN-13: 9784122044500

Ljiljana Markovic

University of Belgrade

Faculty of Philology

\section{MODERNIZATION OF JAPAN - CULTURE AS WELL AS SCIENCE -}

\section{Summary}

Japanese spiritual, ethical, aesthetic, philosophical and literary heritage is woven into the process of modernization of the arts and the progress of science, and therefore overall life in Japan. Through the analysis of philosophical and moral issues of the Later Mito (水戸) School, as well as the overview of the development of Japanese literature, especially prose genres, leading at times towards appearance of trivial literature, the originality and the authenticity of the Japanese creativity is demonstrated, as well as its influence and response to the challenges and the needs of Japanese society's modernization. Modernization of Japan has been successful inasmuch as its path was paved by science, culture and economy.

Key words: Later Mito School, Japanese novel, modernization of Japan. 